\title{
Agency and Compensation: Evidence from the Hotel Industry
}

\author{
MatThew FreEdMan AND RENÁta KosovÁ*
}

October 2010

\begin{abstract}
We examine the relationship between employee supervision and compensation by taking advantage of the structure of the hotel industry, in which many chains have both company managed and franchised properties. Given that supervision is less rigorous at company managed establishments, we estimate differences in wages and human resource practices not only across company managed and franchised hotels within chains, but also within individual hotels as they change organizational form. While we cannot rule out the use of efficiency wages, our results suggest that agency problems affect the timing of pay and employers' propensity to use performance-based incentives.
\end{abstract}

\section{Introduction}

Opportunities for employees to lie, cheat, steal, or slack off abound in most firms. When supervision is difficult or costly, employers may structure pay in ways that mitigate agency problems in the workplace. As Lazear (1981) theorized, tilting the earnings-tenure profile such that wages start below but eventually rise above workers' alternative wages can help to elicit effort from imperfectly monitored employees. To the extent that the minimum wage or other

\footnotetext{
* Freedman: Cornell University, ILR School, 266 Ives Faculty Building, Ithaca, NY 14853 (e-mail: mf439@cornell.edu); Kosová: Cornell University, School of Hotel Administration, 545B Statler Hall, Ithaca, NY 14853 (e-mail:rk373@cornell.edu). We would like to thank John Abowd, Cathy Enz, Kevin Hallock, Jordan Matsudaira, and Emily Owens as well as seminar participants at Cornell's Institute for the Social Sciences for comments on earlier drafts of this paper. We would also like to thank the Cornell Hospitality Research (CHR) Center at Cornell's School of Hotel Administration for helping us obtain the data used in this study and for facilitating the confidentiality agreements.
} 
constraints might limit firms' abilities to lower starting wages, though, it may be advantageous for firms to pay efficiency wages (Shapiro and Stiglitz 1984, Bulow and Summers 1986). Unlike under a simple deferred compensation scheme, the present value of compensation exceeds that of the full-information case with efficiency wages. However, to the extent that they help to attract better workers and discourage opportunistic behavior, efficiency wages may be profitmaximizing for firms that face monitoring problems.

In this paper, we consider the interaction between supervision and compensation in the hotel industry. The nature of hospitality services in general and the structure of the lodging industry in particular make hotels an apt setting in which to examine how differences in supervision levels potentially affect both the level and timing of pay. Unlike in many other labor-intensive industries, the size and physical layout of hotels render technology a poor substitute for close human supervision. Moreover, many hotel chains have both company managed and franchised properties. Relative to managers in company managed hotels, who are salaried employees of a parent company, managers in franchised hotels are residual claimants on profits generated by their properties and therefore have a strong incentive to supervise employees closely. In turn, we would expect franchises to make less use of deferred compensation or efficiency wages to motivate workers.

Exploiting similar variation in organizational form in another hospitality industry, Krueger (1991) examines the extent to which fast food establishments respond to agency problems with delayed compensation schemes or efficiency wages. Krueger shows that relative to restaurants owned and operated by franchisees, those that are owned and managed by parent companies, whose workers generally face lower levels of supervision, pay roughly the same starting wages but have steeper wage-tenure profiles. Krueger's results are consistent with the idea that both 
delayed compensation and efficiency wages are used to help resolve incentive problems in the presence of monitoring costs.

We expand on prior work on the implications of agency problems in the workplace and contribute more broadly to the literature on compensation theory using rich, longitudinal data on limited service hotels, in which general managers are typically responsible for overseeing employees throughout their establishments. Our data, which break out various aspects of compensation for highly detailed occupations within each hotel between 2003 and 2009, allow us to address selection issues and control more effectively than past studies for both observable and unobservable brand and establishment characteristics that might otherwise bias estimates of the effects of franchising on wages and other personnel policies. We do so by estimating differences in compensation and human resource practices not only across company managed and franchised hotels within chains, but also within individual hotels as they transition between company managed and franchised status.

Our results suggest that differences in organizational form affect both the structure of compensation and the use of performance-based incentives in hotels. Specifically, company managed hotels are more likely than franchises to advertise a starting wage above the legislated minimum for nonsupervisory workers. Compared to starting wages, incumbent wages are also higher at company managed properties, indicative of their relatively steep earnings-tenure profiles. Moreover, though company managed hotels typically advertise higher starting pay, they are more likely than franchises to use probationary wages, which effectively tilt the wage-tenure profile and may help to induce sorting among applicants as well as elicit greater employee effort. Finally, franchisees, who may find it easier to evaluate the performance of individual workers 
given the greater resources they devote to supervision, are more likely to offer bonuses to employees and to award raises based on merit rather than on tenure or other considerations.

Overall, our results suggest that hotels use delayed compensation to cope with imperfect monitoring and allay agency problems. Our findings are not inconsistent with the use of efficiency wages, but at the same time, we cannot rule out the possibility that the present values of lifetime wages in hotel industry jobs with different implied levels of supervision are the same. Nonetheless, our results clearly show that variation in supervision levels between hotels with different organizational forms affects the timing of pay and employers' propensity to use certain performance-based incentives.

The paper proceeds as follows. The next section provides a brief overview of the hotel industry's structure and human resource practices. Section III reviews the theory and empirical literature on agency and compensation. In Section IV, we describe our data and provide descriptive statistics. We explain our empirical methodology and present our results on the relationship between organizational form and compensation in Section V. Section VI concludes.

\section{Background on the Hotel Industry}

A. Ownership and Management Structure in the Hotel Industry

The hotel sector has gradually evolved from an industry made up largely of small independent owners to one dominated by several major chains. Overall chain affiliation rose from $35 \%$ in 1970 to over $80 \%$ just 30 years later (Rushmore and Baum 2001). According to the Economic Census, the top four traveler accommodation companies commanded $17.5 \%$ of overall sales in 
the industry in 2002, up from $16.3 \%$ just five years earlier. ${ }^{1}$ Branded hotels are ubiquitous, and individual hotels within chains are often indistinguishable from a customer perspective. However, even two observationally equivalent hotels carrying the same flag may have very different organizational forms. Any given hotel bearing a brand name could be under a franchise agreement, under a management contract, or company owned and operated. ${ }^{2}$

Under a franchise agreement, the parent company of a hotel brand (the franchisor) grants an owner or developer (the franchisee) the right to use its brand name. In this case, the franchisor itself does not offer management services, but rather leaves day-to-day management, including decisions about staffing and pay, to the franchisee. ${ }^{3}$ The franchisee, in turn, is the residual claimant to the profits from the hotel's operations (net of franchise fees and royalty payments). The benefits of brand affiliation for a franchisee include customer name recognition, assistance from the parent company in developing management policies and procedures as well as training programs, and supplier discounts. Also, though a franchisee pays substantial fees to use the brand name and receive these services, ${ }^{4}$ he or she also enjoys the benefits of chain advertising as

\footnotetext{
${ }^{1}$ Economic Census data for the accommodation industry for 2002 can be found at http://www.census.gov/prod/ec02/ec0272i01.pdf. Data for 1997 can be found at http://www.census.gov/prod/ec97/97r72-sm.pdf.

${ }^{2}$ We exclude hotels with no brand affiliation from this analysis because there are relatively few in our data and the information we have on each is more limited. Also, while the theory outlined in this paper would suggest that non-branded hotels might resemble franchises more so than company managed hotels in terms of their employee supervision levels and human resource practices, non-branded hotels undoubtedly differ in many unobservable ways that we may not be able to account for completely.

${ }^{3}$ Franchisees typically have nearly complete control over staffing levels, compensation, and other personnel matters. Hyatt Place's franchise contract, for instance, states that, "Although we [the franchisor] retain the right to establish and periodically to modify System Standards for the Hotel that you agree to implement and maintain, and to modify the Hotel System as we deem best for Hyatt Place Hotels, you [the franchisee] retain the right to control, and responsibility for, the Hotel's day-to-day management and operation and implementing and maintaining System Standards at the Hotel. In addition, our mandatory System Standards do not include any personnel or securityrelated policies or procedures that we (at our option) make available to you in the Manual or otherwise for your optional use. You will determine to what extent, if any, these optional policies and procedures should apply to your Hotel's operations. You acknowledge that we do not dictate or control labor or employment matters for franchisees and their employees and will not be responsible for the safety and security of Hotel employees or patrons." http://www.techagreements.com/agreement-preview.aspx?num=664732

${ }^{4}$ There are a number of different expenses and fees associated with hotel franchise affiliation, and each varies substantially across brands (Blair and Lafontaine 2005). Typically, a franchisee must pay an initial fee with the
} 
well as centralized reservation and referral systems. Franchise contracts with parent companies are generally for a pre-specified period of time (often 20 years).

In contrast, under a management contract, a hotel company contracts with a developer or real estate owner to manage a given property (again, typically for 20 years). The company then brands the hotel property in question and provides management services. The owners in this case, which are often investor groups, cede responsibility for handling operations at the hotel to the parent company (i.e., the operator), which in turn makes all personnel, pricing, and other decisions (Kehoe 1996). As Eyster and deRoos (2009) describe, in a typical management contract, the operator is responsible for selecting, assigning, supervising, training, terminating, and determining compensation for employees. Contracts also generally stipulate that the owner cannot interfere with the operator's management of the property, including personnel decisions.

Neither hotels under management contracts nor franchised hotels are owned by the parent company itself. Company owned and operated hotels exist in many markets, but they account for less than $10 \%$ of total properties that carry a major brand name. In these hotels, as in properties under management contract, off-site parent companies make personnel decisions, including choices about compensation policy.

Individual hotel brands vary in the degree to which their properties are franchised, are under management contract, or are company owned and operated. While several brands are entirely franchised (such as Ramada, Clarion, Microtel, Travelodge, and Howard Johnson), others are

franchise application, plus continuing fees that cover royalties, advertising expenses, reservation fees, frequent traveler programs, and other miscellaneous operations and programs. For example, a franchisee of a Motel 6 in 2008 paid an initial $\$ 25,000$ fee and had to have a hotel with at least 63 rooms. He or she then pays $4 \%$ of gross rooms revenue as a royalty fee as well as $3.5 \%$ of gross room revenue as an advertising/marketing fee annually to the parent company, Accor. To open a Hilton, an initial fee of $\$ 85,000$ applies, 120 rooms are required, and the franchisee pays $5 \%$ of gross room revenue for royalties and $4 \%$ of gross rooms revenue for advertising/marketing. Fees and requirements vary even across brands under the same parent company; TownePlace Suites and Marriott Hotels and Resorts, both under the Marriott International corporate umbrella, have initial fees of $\$ 40,000$ and $\$ 82,500$, respectively, and different royalty and advertising fees, as well (Lodging Hospitality 2008). 
entirely company managed (such as Extended Stay America, Fairmont, and Four Seasons). Many familiar brands are split; for example, over $80 \%$ of Marriott hotel properties are under management contract, while the remaining properties are franchised. Meanwhile, Courtyard by Marriott hotels, which operate under the same parent company (Marriott International), are $60 \%$ franchised and $40 \%$ company managed. The vast majority (over 95\%) of Holiday Inns, Hampton Inns, and Holiday Inn Expresses are franchised, though in each case there are some properties under management contract or company owned (Lodging Hospitality 2009). ${ }^{5}$

Franchising allows a chain to expand more quickly, but can dilute the brand if there is inadequate quality control. ${ }^{6}$ As Rushmore and Baum (2001) discuss, it is very costly for a parent company to monitor individual hotels under franchise agreements. The principal-agent problem that arises between franchisors and franchisees has been explored in past research on the hotel industry (Michael 2000; Kosová, Lafontaine, and Perrigot 2010) and in many other contexts (Caves and Murphy 1976, Rubin 1978, Mathewson and Winter 1985, Holmstrom and Milgrom 1991, Sappington 1991). In this study, we focus not on agency problems that arise in the franchisor-franchisee relationship, but rather on agency problems that arise due to the more limited supervision of employees in company managed hotels (i.e., those under management contract and those that are company owned and operated) relative to franchised hotels. As we describe below, differences in monitoring intensity across franchised and company managed hotels stem from the relatively strong incentives franchisees have to supervise workers closely.

\section{B. Human Resources in the Hotel Industry}

\footnotetext{
${ }^{5}$ Lafontaine and Shaw (2005) show that franchisors typically maintain a stable ratio of franchised to nonfranchised units over time, though the target ratio varies substantially across firms.

${ }^{6}$ See Lafontaine and Slade (2007) for a discussion on franchising and for a review of the empirical literature on the subject.
} 
Jobs in the hospitality sector in general, and in hotels in particular, are predominately low-skilled and low-paying. According to data from the Bureau of Labor Statistics (BLS), average earnings for non-supervisory workers in hotels and other accommodations were $\$ 402$ per week in 2008, compared to $\$ 608$ per week for workers in the private sector as a whole. ${ }^{7}$ Consistent with data we use in this study, the BLS also reports that the average hourly wage for maids and housekeeping cleaners, who account for roughly one-third of all hotel employees, was $\$ 9.74$ in the traveler accommodation industry in 2009, 28 cents less than the average hourly wage for maids and housekeeping cleaners across all industries and less than half of the average hourly wage for all private-sector employees in the U.S. ${ }^{8}$

Given that hotels are open around the clock and employees' work schedules are highly variable, close supervision of workers in the lodging industry is challenging. Additionally, unlike in the fast food industry, where each outlet is relatively small and many tasks are automated, hotels are typically large and jobs are less routinized. As a result, even workers at the lowest rungs of the employment hierarchy within hotels, such as housekeepers, have ample opportunity to shirk and otherwise behave opportunistically (Wood 1992). As a former hotel housekeeper notes,

I cut corners everywhere I could. Instead of vacuuming, I found that just picking up the larger crumbs from the carpet would do. Rather than scrub the tub with hot water, sometimes it was just a spray-and-wipe kind of day... After several weeks on the job, I discovered that the staff leader who inspected the rooms couldn't tell the difference between a clean sink and one that was simply dry, so I would often just run a rag over the wet spots... I apologize to you now if you ever stayed in one of my rooms. You deserved better. But if housekeepers were paid more than minimum wage - and the tips were a bit better - I might have cleaned your toilet rather than just flushed it. (Rupp 2009, 31)

In addition to "cutting corners," theft by employees is common in the lodging industry. A recent survey of hotels in Grand Strand/Myrtle Beach region of South Carolina revealed that the

\footnotetext{
${ }^{7} \mathrm{http} / / / \mathrm{www} \cdot$ bls.gov/oco/cg/cgs036.htm

8 http://www.bls.gov/oes/current/oes372012.htm
} 
average hotel experienced between four and five thefts perpetrated by employees in the previous two years, with losses ranging from $\$ 40$ to tens of thousands of dollars (Krippel 2008). Another study examined police records on crimes reported by 64 Miami Beach hotels in 2002 and 2003 and also found evidence of widespread employee theft (Brown, Ho, and Zhao 2009). Of the 756 crimes against guests at the Miami hotels, about half were thefts, and 38\% occurred in hotel rooms. Also revealing was the fact that more crimes against guests at hotels occurred in the afternoon than any other time of day. The authors contend that most of these crimes are committed by hotel employees and suggest that imposing high costs to being caught stealing as well as close supervision are crucial to theft prevention.

Since they are residual claimants to profits generated by their properties, franchisees have a stronger incentive to monitor individual employees closely than managers of company managed hotels. Moreover, franchisees are often native to the areas in which their hotels are located, and to the extent that they are familiar with the local labor market, culture, demographics, and overall business environment, they may have less need to offer higher wages to attract and retain good workers. On the other hand, salaried managers in company managed properties, whose pay is not tied directly to the performance of their property and who are commonly transferred from hotels in other markets (Kennedy and Fulford 1999), may be less willing to supervise employees closely and less able to recruit good workers without offering higher wages. Krueger (1991) presents evidence that employees are supervised more closely in franchised fast food restaurants than in company owned fast food restaurants, which he attributes to the different incentives franchisees and salaried managers face. As summarized by Stephen P. Holmes, CEO of Wyndham Worldwide Corporation, the incentive structure is very similar in the hotel industry, where for franchisees, "entrepreneurial spirit drives the desire [to work hard] because your net 
worth is tied up in the hotel. That tends to get your attention and pushes you" (Warren 2006, 23).

A franchisee of a limited-service Microtel in Northern Virginia also noted that a franchisee must "understand how to make the business profitable. You work very long hours. When you open a hotel, you never lock the door again..." (Smith 2001). ${ }^{9}$

Hotels in which supervision is more lax may be obliged to adopt personnel policies aimed at discouraging opportunistic behavior. Indeed, the above quote from Rupp (2009) suggests that there may be a trade-off between higher pay and benefits on the one hand and closer monitoring on the other. While labor costs represent about one-third of revenues at the typical hotel, there is substantial variation around the mean (Walker and Miller 2010). As Enz and Siguaw (2000) further discuss, there are significant differences across hotel chains in their strategies for attracting, retaining, training, and promoting workers. There is little direct evidence on differences in supervision or management practices across hotels with different organizational forms. However, the evidence available for the lodging industry points to variation in personnel practices among franchised and company managed properties within chains consistent with that found in the fast food industry, where studies suggest franchises implement different, and typically more low-road, human resource practices than do their company managed counterparts (Krueger 1991, Bradach 1998). As Umbriet (2003) describes, relative to franchises, chain corporate hotels more frequently use management-by-objectives (MBO) techniques, which emphasize individual objective setting and offer more autonomy to individual employees. This is consistent with company managed hotels having a limited ability to supervise workers closely.

\footnotetext{
${ }^{9}$ All else being equal, differences in effort levels among franchisees and salaried managers at company managed hotels might be expected to improve profitability (Shelton 1967) or other performance outcomes for franchises relative to company managed hotels. However, in general, omitted variable bias and endogeneity problems associated with the choice of organizational form make it difficult to infer causality from any observed relationship between franchise status and performance. Studies that have attempted to account for the endogeneity of organizational form among hotels (e.g., Kosová, Lafontaine, and Perrigot 2010) have focused on revenues and prices, not costs or overall profitability.
} 
Also, in a survey by Yang (2004) of employees at two upscale hotels, one of which was under management contract and one of which was franchised, workers at the former tended to be much more autonomous and engaged in decision-making, whereas workers at the latter appeared to be more passive and deferential to superiors.

Anecdotal evidence suggests that differences in organizational form, and in turn, the relationship between employers and employees, are associated with differences in compensation. One anonymous employee of Starwood Hotels and Resorts pointed out in an online forum that “franchise properties are not good to work for because they don't have the same structure or benefits as the corporate hotels. ${ }^{" 10}$ Similarly, an anonymous desk clerk at a Choice Hotel in Oxford, Alabama noted that "the lack of benefits or pay" was one negative aspect of working at a franchised hotel, and contended that "the francise $[s i c]$ owners should have to abide by some type of corporate standard for pay and benefits." ${ }^{, 1}$

\section{Agency and Compensation}

A large and growing body of research in personnel economics focuses on the methods firms use to address problems of asymmetric information between employers and their employees regarding underlying ability levels, intentions to remain in or leave jobs, and effort levels. If supervising workers is costly or difficult, then in order to mitigate principal-agent problems, employers may adopt a delayed compensation (or bonding) scheme, efficiency wages, or both. Formal theoretical models of each have been developed elsewhere (Lazear 1979, 1981; Lazear

\footnotetext{
${ }^{10} \mathrm{http}: / /$ www.glassdoor.com/Reviews/Starwood-Hotels-and-Resorts-Reviews-E335.htm

${ }^{11}$ http://www.glassdoor.com/Reviews/Choice-Hotels-Reviews-E6757.htm
} 
and Moore 1984; Shapiro and Stiglitz 1984; Yellen 1984), so in this section we provide only the basic intuition. $^{12}$

In a bonding model, firms elicit effort from employees by forcing them to post a bond upon beginning work, a bond they forfeit if they are fired for shirking. Though firms in the hotel industry (and most other industries) do not explicitly require workers to post such bonds, the model provides insight into nature of the agency problem and potential solutions. Suppose that the cost of exerting effort for a worker is $e>0$, so in essence a worker places some positive value to shirking on the job. In the absence of any bonds and assuming a competitive labor market in which individuals accumulate only general skills, the worker will shirk since there is effectively no penalty to doing so. A worker fired for slacking off, stealing, or otherwise behaving opportunistically can immediately find employment elsewhere.

However, if an employer requires a new employee to post a bond in the amount $B$ that must be repaid if that employee is caught shirking, such opportunistic behavior can be discouraged. Specifically, if a worker who shirks is caught with probability $p$, then he or she stands to lose $p B$ in expectation. Assuming the worker is risk neutral, he or she will not shirk as long as the expected cost from doing so is greater than the gain, or as long as $e \leq p B$. For a given $e$, a lower probability of detection requires a larger bond to discourage shirking (Moretti and Perloff 2002).

Though we rarely observe workers post upfront bonds, they may implicitly do so by accepting a compensation scheme in which payment is backloaded. ${ }^{13}$ In a deferred compensation scheme, firms tilt the wage tenure profile such that wages are higher later in a workers' tenure

\footnotetext{
${ }^{12}$ For a broader review of the theoretical and empirical literature on incentives within firms, see Prendergast (1999).

${ }^{13}$ Rebitzer and Taylor (1995) suggest that employees effectively post large bonds in law firms by accepting low wages early in their careers. They also find large, persistent firm size-wage effects in law firms, a result that runs counter to the idea that efficiency wages are being used as an incentive device. However, their results are not inconsistent with the idea that large firms pay higher wages to attract a better pool of workers.
} 
than earlier. To illustrate how this may help to incentivize workers, we consider a simplified version of Lazear (1979) that draws on Ritter and Taylor (1997).

Assume that workers can choose either to work hard, in which case they incur a cost $e>0$, or to shirk, in which case they incur no cost. Suppose that a worker is indifferent between exerting effort $e$ on a given job and earning $W^{H}$, shirking on the job and earning $W^{L}$, and not having the job. In that case, the difference between $W^{H}$ and $W^{L}$, the reservation wages associated with high effort and no effort, respectively, is equal to $e$, the value the worker attaches to shirking (or the monetary value of exerting effort). If an employee works hard, his or her marginal revenue product, $M R P^{H}$, is higher than if he or she shirks on the job, $M R P^{L}$. If productivity is only a function of effort, it will be optimal for firms that value high productivity relatively highly $\left(M R P^{H}-M R P^{L} \geq e\right)$ to pay $W^{H}$, and for firms that value high productivity relatively less to pay $W^{L}$

However, if there is imperfect monitoring, simply paying $W^{H}$ will not guarantee high effort given that workers have outside options to which they are indifferent. As Lazear (1979) points out, though, tilting the earnings profile such that wages start below and rise above (the constant) $W^{H}$ will mitigate the shirking problem. If workers care only about the present value of their lifetime stream of earnings and have full access to credit markets, they will be indifferent to wage-tenure profiles with different slopes as long as their present values are the same (and are at least as much as the present value of their lifetime production). ${ }^{14}$ Therefore, a necessary

\footnotetext{
${ }^{14}$ To the extent that a deferred compensation scheme discourages shirking and thereby raises a firm's overall productivity, those firms that adopt such a scheme will also be able to pay more over a worker's lifetime. However, a steeper wage-tenure profile poses risks to a worker; in particular, if a firm shuts down or dismisses a worker for reasons other than shirking, a worker will be harmed more if he or she is paid according to a deferred compensation scheme as opposed to a scheme in which wages track his or her MRP. To prevent opportunistic firing by a firm, there must also be some provisions that preclude firms from reneging on their implicit contracts with workers once wages rise above their MRP. However, there also must be ways to prevent workers from lingering beyond the time at which the present value of earnings and productivity are equalized (Lazear 1979, 1981).
} 
condition for any underpayment-followed-by-overpayment scheme to work is that the present value of per-period wages and the present value of the constant wage $W^{H}$ are equalized, or

$$
\sum_{t=0}^{T}\left(\frac{1}{1+r}\right)^{t} W_{t}=\sum_{t=0}^{T}\left(\frac{1}{1+r}\right)^{t} W^{H}
$$

where $W_{t}$ is the wage paid at time $t$ and $T$ is the date of retirement. The $L Q$ curve in Figure 1 illustrates a possible lifetime wage profile that satisfies this condition. Except for during the last period, there is no incentive for a worker to shirk with a wage profile like $L Q$. This can be verified by noting that at any time $s$ during a worker's life, given a probability that a shirking worker will be caught is $p$, he or she will be discouraged from shirking as long as

$$
e \leq p \sum_{t=s}^{T}\left(\frac{1}{1+r}\right)^{t-s}\left(W_{t}-W^{H}\right)
$$

Thus, at least until the last period, a firm can induce effort by tilting the wage-tenure profile, and ultimately pay no more or less than if it were to pay a constant wage that tracked a worker's MRP exactly. ${ }^{15}$ We can couch the previous bonding example in this theoretical framework; referring back to Figure 1, an employee could post a bond equal to $L-M=B$, then receive a constant wage $D$ (where $K-M$ is the interest on the bond) until retirement, when the firm repays the principal (equal to $Q-H$ ) (Lazear 1979).

\footnotetext{
${ }^{15}$ At time $T$, a worker has an incentive to shirk since there is no penalty so close to retirement. However, as Lazear (1979) notes, a firm could tailor a worker's pension, which is received after retirement, to discourage shirking in the final period.
} 
Hence, under a deferred compensation scheme, workers are effectively lending money to the firm early in their careers that will be paid back in the future. In that sense, workers with deferred compensation are bond holders; by accepting pay that is below what they are worth early in their careers, they implicitly buy bonds from their employer, which in turn pays back the principal and interest, but only to those employees not fired for shirking. Thus, a wage structure in which wages are low compared to workers' best outside options early in their careers, but rise above them later, will help to discourage shirking by workers who know that such behavior could result in their premature dismissal and thus jeopardize their chances of winning higher wages.

Firms may prefer a steeper profile to a flatter one not only because of its incentive effects, but also because of its potential sorting effects. Delayed compensation schemes will attract only employees who are committed to long-term relationships with employers. This, in turn, renders training investments less risky for firms.

In lodging as well as many other low-wage industries, some firms adopt probationary wages for new employees, which serve to tilt the wage-tenure profile. However, in general, a compensation scheme that involves underpayment followed by overpayment can be difficult to implement by firms in low-wage industries. Such firms might be limited in their ability to reduce wages relative to workers' outside options early in employees' careers for a number of reasons. For example, minimum wages may preclude firms from paying low initial wages. ${ }^{16}$ In that case, a delayed compensation scheme, which is a first-best solution in the sense that ex-ante employment decisions are not affected by it relative to the full-information case, may not be

\footnotetext{
${ }^{16}$ Other reasons offered in the literature for the rarity of bonding include the fact that American and English courts are reluctant to enforce contract provisions interpreted as penalties, and although firing is generally not viewed as a penalty, the forfeiture of a performance bond is (Dickens et al. 1989). Also, the outlawing of mandatory retirement has arguably interfered with the use of bonding and delayed compensation as incentive mechanisms (Lazear 1979). Additionally, moral hazard for the firm could pose a challenge to implementing a bonding or delayed compensation scheme; since firms have an incentive ex-post to misrepresent a worker's performance, workers may be reluctant to ever enter contracts that involve bonding or delayed compensation (Ritter and Taylor 1997).
} 
feasible. Instead, firms may adopt efficiency wages to address the principal-agent problem. Efficiency wages are above-market levels of pay that may help to improve productivity and reduce shirking. They may do so by helping to generate a larger and more qualified pool of applicants (and thereby allowing owners to be more selective in their hiring), by increasing the gap between workers' current wage and their outside opportunities (and thus increasing the cost of being fired), and by fostering feelings of equity or fairness among employees in the firm (Akerlof and Yellen 1986).

Returning to our example, if we assume that firms cannot offer workers any wage lower than their best outside options, then $W_{t}$ must be greater than or equal to $W^{H}$ at all points in time. Therefore, to elicit effort, a firm would have to offer a stream of earnings greater in present value than that offered under the deferred compensation scheme. In other words, when bonding cannot be used to solve the agency problem, firms must offer an efficiency wage. One example of a profile in which the potential to use bonding is limited and efficiency wages are used is $M N$ in Figure 1.

Even if there is some potential to use deferred compensation as an incentive device, to the extent that it cannot fully resolve the agency problem, a firm will need to pay a premium to induce effort. The optimal stream of efficiency wages equalizes the left-hand and right-hand sides of equation (2), subject to any constraints on the wage that can be set in any given time period. In effect, the firm must adjust compensation such that, at any given point in time, the present value of wages yet to be received equals $e / p$ (Ritter and Taylor 1997). ${ }^{17}$

\footnotetext{
${ }^{17}$ Since firms that pay efficiency wages are paying a premium, they demand fewer workers and produce less than firms that do not need to pay efficiency wages. Therefore, all else being equal, a firm that faces agency problems will be at a competitive disadvantage. Therefore, in order to survive in the market, firms that pay efficiency wages must have equilibrium MRPs higher than the equilibrium MRPs of firms that do not.
} 
Note that this implies that firms can use efficiency wages and deferred compensation together; if firms can tilt the wage-tenure profile, it will reduce the need for efficiency wages to encourage employees to work hard. This also makes clear that if monitoring costs are high ( $p$ is low), as is likely the case in the hotel industry more so than in many other low-wage industries, the wage profile will need to be steeper or, to the extent that tilting the profile is not possible, the efficiency wage premium will have to be greater. ${ }^{18}$

A number of empirical studies have sought to determine the extent to which firms use deferred compensation or efficiency wages to address agency problems. Hutchens (1987) shows that jobs that involve more repetitive tasks, and thus are arguably easier to monitor, tend to have flatter wage-tenure profiles. Raff and Summers (1987) suggest that Henry Ford's \$5 per day wage in the 1910s was an efficiency wage, and that in line with the theory, it induced worker sorting, elicited effect, and reduced turnover. Krueger and Summers (1988), meanwhile, argue that the fact that observationally equivalent workers are paid different amounts in different industries suggests that efficiency wages are important. However, Leonard (1987) finds that higher levels of supervision in plants are not associated with lower wages.

Krueger (1991) uses two cross-sectional datasets of employees of fast food restaurants to examine the use of deferred compensation and efficiency wages in the industry. His data allow him to control for many worker and restaurant characteristics in estimating differences between company owned and franchised outlets in the timing and level of pay. Krueger finds that relative to franchised outlets, company owned properties pay roughly the same initial wages, but offer

\footnotetext{
${ }^{18}$ While pay and supervision are substitutes when the choice over effort levels is dichotomous (all or nothing) and the source of variation across firms is in monitoring costs, they may be complements when effort is a continuous outcome or when the source of variation across firms is in the return to effort (Prendergast 1999, Allgulin and Ellingsen 2002). In our application, we consider nonsupervisory and mainly entry-level positions among hotels with the same brand-determined quality standards. As such, desired effort levels are unlikely to vary substantially with monitoring costs, and variation across firms in the return to effort is likely small relative to variation in the costs of supervision.
} 
steeper wage-tenure profiles, particularly for mid-level employees for whom output is hardest to measure and individual effort levels difficult to assess. Additionally, compared to franchised establishments, company owned stores typically provide more perks to employees, including free meals, paid vacation days, and other benefits. These patterns are consistent with company owned restaurants responding to more limited monitoring by adopting a combination of efficiency wages and deferred compensation. Each method of compensation could help to discourage opportunistic behavior as well as attract higher quality applicants who, once hired, may have a lower likelihood of leaving the firm or shirking on the job. Similarly, to the extent that supervision levels are lower in hotels that are company managed as opposed to franchised, they may adopt pay arrangements for employees aimed at addressing the more pronounced principalagent problem.

\section{Data}

\section{A. Data Sources}

To study how organizational form and variation in monitoring intensity affect the compensation and human resource practices within establishments, we take advantage of panel data on hotels obtained from the Smith Travel Research (STR) Company and WageWatch, Inc. ${ }^{19}$ The STR data cover over $98 \%$ of existing U.S. hotel properties in any given year and provide for each establishment a unique hotel identifier, parent company and brand identifiers, number of rooms, opening date, information about amenities (e.g., if the hotel has a restaurant, convention or

\footnotetext{
${ }^{19}$ STR is an independent research firm that collects information about hotel properties in the U.S. and internationally. Its census of hotels represents the most comprehensive data source on the hotel industry available. WageWatch is an independent company that collects data on compensation from thousands of businesses across several industries in the U.S. for use by human resources departments and executives in making hiring decisions and in determining pay and benefit levels for employees. Both companies provided us access to their databases under strict confidentiality agreements.
} 
conference facilities, extended stay rooms, etc.), features of the location (e.g., if the hotel is near an airport, on an interstate, part of a resort, etc.), and county. ${ }^{20}$ Also, for nearly all branded hotels, STR collects monthly information on hotel revenues as well as rooms available and sold. We use these monthly data to construct revenue per available room (or RevPAR as it is termed in the industry), a commonly used measure of financial performance in the hotel sector that reflects both room rates and occupancy. For each hotel, we calculate an annual average of RevPAR and deflate it by the consumer price index for all urban consumers (CPI-U) to reflect inflationadjusted 2009 dollars.

Information in the WageWatch data includes for each occupation in each hotel by year the number of employees, the advertised starting wage (or salary if pay is not hourly), the lowest actual wage (or salary) currently paid, the average actual wage (or median salary) currently paid, and the highest actual wage (or salary) currently paid. For the purposes of our analysis, we convert all annual salary information into hourly wages, and then deflate wages by the CPI-U to reflect inflation-adjusted 2009 dollars.

In addition to the wage variables, the WageWatch data include information not only on whether employees in each occupation receive bonuses, ${ }^{21}$ but also on whether raises are awarded on the basis of merit or otherwise. ${ }^{22}$ Additionally, we have information on whether employees in each occupation within a hotel are unionized and whether employees are subject to a

\footnotetext{
${ }^{20}$ Actual hotel, brand, and parent company names have been replaced with numeric identifiers in the data to maintain their confidentiality.

${ }^{21}$ The WageWatch data separate bonuses from wages. However, hotels in the survey report bonus amounts using a wide variety of metrics (e.g., in dollars; in percent of weekly, monthly, or annual pay; in numbers of days, weeks, or months worth of wages; etc.) for which we have no documentation. Additionally, the frequency of bonuses is not always reported. Hence, we only use information on whether a hotel ever pays a bonus each year. However, given the structure of the survey, we can be confident that bonuses are not reflected in reported wages.

${ }^{22}$ If raises are not awarded on the basis of merit, they could be flat/across-the-board raises (i.e., non-discretionary compensation that does not vary according to performance), step raises (i.e., standard progression pay rates that are established in a pay range), or tenure-based raises.
} 
probationary adjustment, or an increase in pay awarded after a probationary period (typically lasting 60-90 days).

Data from WageWatch cover the years 2003-2009. In our analysis, we focus on limited service hotels, which represent smaller properties that emphasize basic room accommodations and amenities and in which the general manager typically directs all activities and oversees employees across departments (Stutts and Wortman 2006). ${ }^{23}$ In such hotels, the hiring of supervisors is less likely to mediate the relationship between a manager's level of effort and the pay of nonsupervisory employees. Limited service hotels are also less likely than their full service counterparts to offer employees other benefits, such health insurance, that might compensate for lower wages (Beauchamp and Mandelbaum 2009). ${ }^{24}$ To ensure that differences in occupational distributions across hotels do not affect the results, we focus on the 30 largest non-supervisory positions, which comprise about $90 \%$ of the total workforce. ${ }^{25}$

After dropping observations with missing information on our key dependent and explanatory variables and excluding unbranded hotels, our final sample encompasses 2,686 unique limitedservice hotels distributed across 436 counties and representing 82 brands that operate under 18

\footnotetext{
${ }^{23}$ See also the Bureau of Labor Statistics' Occupational Outlook Handbook, 2010-11 Edition. http://www.bls.gov/oco/ocos015.htm.

${ }^{24}$ WageWatch does not collect reliable information on health insurance or other fringe benefits such as free meals, free or discounted hotel rooms, flexible work schedules, or vacation time. These are all margins on which company managed hotels might differ from franchised properties, but for which we do not have data. However, benefits are not particularly commonplace in the lodging industry; according to the BLS's 2009 National Compensation Survey (NCS), only $41 \%$ of accommodation and food services establishments offer health care benefits (http://www.bls.gov/ncs/ebs/benefits/2009/). Consistent with the NCS, according to the 2008 American Community Survey, only $42 \%$ of maids and housekeeping cleaners working in the traveler accommodations industry report having employer or union-provided health insurance. These shares are likely even lower in the relatively small, limited service hotels we consider (Beauchamp and Mandelbaum 2009).

${ }^{25}$ The 30 occupations include accountants, administrative assistants/department secretaries, banquet servers/waiters/waitresses, banquet set-up/house persons, bartenders, bell persons, breakfast attendants, bus persons, cooks - breakfast, cooks/line cooks, door persons, drivers - van/shuttle, food servers/wait staff, front desk agents, group rooms coordinators, housekeepers - entry-level, housekeepers - advanced, laundry attendants, lobby/public areas attendants, maintenance technicians - entry-level, maintenance technician - semi-skilled, maintenance technician - skilled, night auditors, restaurant hosts/hostesses/greeters, room service servers, sales managers - entry level, sales managers - intermediate, security officers/guards, stewards/dishwashers, and switchboard operators.
} 
parent companies. The panel is unbalanced, as the composition of hotels and occupations in those hotels changes over time. All together, we have 29,579 occupation-hotel-year observations. $^{26}$

While WageWatch collects a wealth of information on employment and compensation for each occupation in each hotel, it does not collect information on the characteristics of individual employees. A legitimate concern is that pay levels may vary within occupation across franchised and company managed hotels because they hire different types of workers (e.g., one hires more educated individuals to work as bellhops than the other) or because their employees have different average tenure levels. ${ }^{27}$ If this is the case, the pay differences we attribute to differences in monitoring costs might in fact be attributable to differences in underlying worker characteristics. While we cannot control for worker characteristics directly, the high level of occupational detail in our data mitigates this concern to a large extent. The data break out even highly disaggregated occupation categories, such as maintenance technicians, into even finer detail, including entry-level, semi-skilled, and experienced maintenance technicians. WageWatch as opposed to individual hotels categorize occupations, which helps to ensure that the profile of

\footnotetext{
${ }^{26}$ All the information in the WageWatch data are provided voluntarily by hotels, which in return receive information on compensation practices of other hotels in the same area and segment. They generally use this information for the purposes of benchmarking compensation within markets. Our methodology and conclusions do not depend on the profile of hotels in our sample matching that of the entire hotel industry. However, given that we can identify those hotels that do and do not subscribe to WageWatch, we can compare the characteristics of our STR-WageWatch matched sample to the population of hotels to shed some light on the representativeness of our sample. In line with the broader population of limited-service branded hotels, hotels in the matched sample are $71 \%$ company managed and 29\% franchised (see Table 1). Hotels in the matched sample skew somewhat younger and larger (in terms of number of rooms) and are more likely to be in urban areas than the typical hotel. Hotels in our matched sample are also more likely than average to have restaurants, convention and conference facilities, and allsuites rooms. However, the geographic distribution of hotels in the matched sample is similar to that of the entire population of hotels, with almost equal shares in each region of the U.S.

${ }^{27}$ Franchisees may have an incentive to free ride on the brand reputation and apply a lower standard to the quality of services they offer to customers. If this is the case, they may hire lower quality workers. However, Brickley and Dark (1987) and Brickley, Dark, and Weisbach (1991) find little evidence to support the notion that free-riding is an important source of variation in quality across franchised and company managed establishments. In addition, we exploit hotel amenity, brand, price, and location information to help to control for any quality differences that may exist between franchised and company managed properties.
} 
workers within each occupation is similar across hotels. Moreover, in contrast to previous studies that relied on cross-sectional data, our panel data allow us to control for unobserved occupation and location effects as well as a number of time-varying observable and time invariant unobservable hotel and local area characteristics. This, together with our focus on limited service hotels, not only helps to address any omitted variable bias or endogeneity stemming from selfselection, but also helps to mitigate any bias that might arise due to a lack of direct information on employee characteristics. Finally, in one robustness check, we examine differences in compensation and human resource practices across company managed and franchised hotels in specific occupations in which we might expect relatively less heterogeneity in underlying worker characteristics.

To control for time-varying market characteristics, we combine the STR-WageWatch matched data with annual information from the Bureau of Labor Statistics (BLS) and the Census Bureau on county characteristics. For each county, these variables include total employment, the average weekly wage (both from the Quarterly Census of Employment and Wages and measured in the second quarter of each year), the unemployment rate (from the Local Area Unemployment Statistics database), and the share of the population that is black (from the Census Bureau's population estimates). ${ }^{28}$

In our analysis, we group company owned and operated hotels together with hotels under management contract under the heading “company managed.” As Kehoe (1996) notes, company owned and operated hotels and hotels under management contracts require about the same

\footnotetext{
${ }^{28}$ We also experimented with including other county demographic characteristics, including the share of the population in different age categories and the share of non-US citizens. Their inclusion did not change our results. Notably, we use employment instead of population as a control because hotels are attracted more to highemployment commercial centers than to residential areas. However, using population instead of employment as a control did not affect the results.
} 
amount of monitoring by the parent company. In any case, less than $1 \%$ of the hotels in our sample of limited service hotels are company owned and operated.

\section{B. Descriptive Statistics}

Statistics comparing the characteristics of company managed and franchised limited service hotels in our sample and comparing the compensation policies of each type of hotel appear in Table 1. As Panel A shows, on average, franchised and company managed hotels are similar in size (about 127-128 rooms), though franchised hotels tend to be slightly younger (the average opening year for franchised hotels is 1995 , compared to 1994 for company managed hotels). Unionization rates in our sample of hotels are generally low, but franchised hotels are somewhat more likely to have unionized workers than company managed hotels (3\% vs. 1\%). Franchised hotels are also more likely to have a restaurant on the premises $(17 \%$ vs. $5 \%)$. In terms of their typical locations, franchises are more likely to be in urban cores of cities as well as along interstates and in rural areas, while company managed properties are more likely to be in suburbs. However, while franchised properties are somewhat more common in the Northeast and company managed properties are somewhat more common in the South, the geographic distribution of limited service hotels in our sample across the U.S. under each organizational form is otherwise similar.

Among the subset of hotels for which we have data on performance, franchised hotels have higher average RevPAR, which may in part reflect the greater effort put into running hotels by franchisees relative to salaried managers. However, there are other differences between company managed and franchised hotels that could explain the variation in average performance, and organizational form itself is likely to be endogenous with respect to RevPAR (Kosová, 
Lafontaine, and Perrigot 2010). We explore this issue and its potential implications for compensation in Section V.B.4.

Despite the differences in performance, the occupational composition of franchised and company managed hotels in our sample is similar. Figure 2 shows the average representation of each of the top ten largest nonsupervisory occupations within company managed and franchised hotels. The workforce of the average company managed hotel and the average franchised hotel is comprised of roughly equal shares of housekeepers (32-34\%), front desk agents (18-21\%), food servers $(9 \%)$, drivers (7-9\%), and most other occupations. In other words, the occupational distribution in company managed hotels is very similar to that of franchised hotels, which suggests that staffing policies differ little between hotels under each organizational form.

While franchised and company managed hotels are staffed similarly, their compensation strategies appear to be quite different, as Panel B of Table 1 shows. At \$8.71 (in 2009 dollars), average advertised starting wages in franchises are $\$ 0.45$ lower than in company managed hotels, a difference significant at the $1 \%$ level. Average wages for the highest paid incumbent are also a statistically significant $\$ 0.64$ lower in franchises. These differences are striking, especially given that company managed hotels tend to have lower RevPAR on average.

Meanwhile, though the difference is not statistically significant, the average ratio of the highest paid incumbent wage to the starting wage within occupations is greater in company managed hotels on average, suggestive of a steeper earnings-tenure profile. Further, company managed hotels in our sample are significantly more likely to use probationary wages, which also serve to steepen wage-tenure profiles. However, one is more likely to find starting wages equal to the minimum wage in franchises than in company managed hotels. ${ }^{29}$ The unconditional

\footnotetext{
${ }^{29}$ We compiled data by state and year on minimum wages using information from the U.S. Department of Labor (http://www.dol.gov/whd/state/stateMinWageHis.htm).
} 
comparisons of means in Table 1 also suggest that while company managed hotels are more likely to give raises on the basis of merit rather than for other reasons, franchised hotels are more likely to offer bonuses.

One possible explanation for differences in compensation at company managed hotels relative to franchised hotels is that salaried managers at the former do not minimize costs. Salaried managers may, for example, pay higher wages to reduce their own workload (e.g., by reducing complaints among staff), in which case the observed differences in pay may have little to do with differences in supervision. However, wages and other personnel policies in the hotel industry, like in the fast-food industry considered by Krueger (1991), are generally set at the regional level as opposed to the establishment level for company managed properties (International Labour Organization 2001). To the extent that wages and other personnel policies are not at the discretion of their salaried managers, a failure to minimize costs in company managed hotels could not explain the observed differences. Nevertheless, in an effort to validate our assumption that organizational form is in fact capturing variation in supervision levels as opposed to other differences between company managed and franchised hotels, in the analysis that follows, we examine differences in compensation and human resource practices across company managed and franchised hotels in specific occupations in which we would expect monitoring problems to be more or less pronounced. ${ }^{30}$

\footnotetext{
${ }^{30}$ To the extent that there is potential for career advancement and that parent companies can evaluate individual manager performance, general managers at company managed hotels may still have incentives to supervise workers closely to ensure high quality and strong financial performance. Our discussions with industry experts and anecdotal evidence suggest that internal labor markets are generally better developed in larger hotel chains, but that even in such chains, opportunities for promotion to more desirable hotels in the chain or to regional or central offices are limited and generally require relocation. As a night auditor at a Marriott observed in an online forum, "It's extremely hard to move up within one property. Promotions are few and far between, unless you're willing to move to another property" (http://www.glassdoor.com/Reviews/Employee-Review-Marriott-RVW366874.htm). Nonetheless, if managers in company managed hotels are motivated by the prospect of advancement within the firm, it could reduce differences between company managed and franchised hotels in the degree of employee monitoring.
} 
Another potential confounding factor is that some franchisees own more than one property. Multi-unit franchises are less common among the limited service hotels we consider than among full service hotels. ${ }^{31}$ Nonetheless, the fact that some franchisees operate more than one hotel could lead to bias in our results. That bias, however, will be toward finding no difference between company managed and franchised hotels in terms of their compensation policies; the more hotels a franchisee operates, the more the franchisee resembles a parent company in that monitoring workers at each individual property becomes more difficult.

\section{Empirical Analysis}

\section{A. Specifications}

In order to estimate the relationship between compensation and organizational form, which proxies for differences in monitoring intensity, we estimate variations on the following regression:

$$
y_{i j k m t}=\alpha * \text { company }_{j k m t}+\beta * \text { union }_{i j k m t}+\mathbf{Z} \mathbf{\Omega}_{j k m t}+\mathbf{M} \Psi_{m t}+\delta_{i}+\gamma_{k}+\psi_{m}+\eta_{t}+\varepsilon_{i j k m t}
$$

where $y$ is the wage or human resource policy outcome of interest (discussed further below) in occupation $i$ in hotel $j$ of brand $k$ in county $m$ at time $t$. The independent variable of most interest, company, is a dummy variable that takes a value of one if hotel $j$ is company managed in a given year and zero if it is franchised. If an occupation within a hotel is unionized, union takes a value

In this case, however, we would expect to find no significant differences between compensation and human resource practices between hotels with different organizational forms.

${ }^{31}$ For example, only about $1 \%$ of franchisees of hotels brands in the InterContinental Hotels Group, whose limited-service brands include Candlewood Suites, Holiday Inn, and Holiday Inn Express hotels, own more than one unit. Only $10 \%$ of Motel 6 franchisees and $15 \%$ of Super 8 franchisees own more than one unit. About one-fifth of franchisees of Choice Hotels, which include limited-service chains Sleep Inn, Comfort Inn, Quality Inn, Clarion, Rodeway Inn, and Econolodge, own multiple units. For more details, see http://www.entrepreneur.com/franchises/. 
of one, but otherwise is zero. $\mathbf{Z}$ is a vector of hotel characteristics, including hotel size (measured as the natural log of the number of rooms), hotel age (in years), six indicators for location type (urban, airport, interstate, resort area, suburban, and rural), five indicators for various hotel services or amenities (extended stay, restaurant, conference facilities, boutique, and all suites), and indicators for each of five possible market-specific price range quintiles into which a hotel falls. ${ }^{32}$ These hotel-level characteristics help to control for differences in the scale and quality of hotel operations, which might affect compensation practices and be correlated with organizational form. $\mathbf{M}$ is a vector of local market characteristics, including the natural $\log$ of county employment, the county unemployment rate, the share of the county population that is black, the natural log of county average weekly wage, and the number of other hotels in the county (the latter derived from the STR census database). These variables help to control not only for time varying economic and demographic characteristics of the local market, but also for changes over time in industry structure, and competition. Including the number of other hotels in the county also helps to control for changes in local tourism activity. Finally, $\delta$ is an occupation fixed effect, $\gamma$ is a brand fixed effect, $\psi$ is a county fixed effect, $\eta$ is a year fixed effect, and $\varepsilon$ is the idiosyncratic error term. The fixed effects help to control for unobserved heterogeneity at occupation, brand, location, and year levels that may affect compensation and be correlated with organizational form. All regressions are weighted by the number of workers in each occupation in each hotel, and standard errors are adjusted for heteroscedasticity and clusters at the hotel level.

\footnotetext{
${ }^{32}$ The STR-defined price range indicators are market-specific and based on average daily room rates. In metropolitan markets, the five indicators are defined as the top $15 \%$ of the average daily room rate (luxury), second $15 \%$ (upscale), middle 30\% (mid-price), next 20\% (economy), and bottom 20\% (budget). In non-metropolitan or rural markets, the luxury and upscale price categories are collapsed into one category constituting the top $30 \%$ of the average daily room rate.
} 
In this specification, the effects of differences in organizational form on outcomes are identified off variation across hotels within geographic regions, brands, and occupations as well as over time. Given the panel nature of our data, we can go one step further by replacing the county fixed effect with a hotel fixed effect. ${ }^{33}$ In doing so, we exploit variation in organizational form over time within hotels to determine whether being franchised or company managed, with their different implied levels of employee supervision, affects outcomes. This latter specification relies on the fact that some hotels switch from being franchised to company managed or vice versa over the sample period. While not particularly common (35 hotels change organizational form in our sample, two-thirds of which switch from franchised to company managed and onethird of which switch from company managed to franchised), these changes among individual hotels allow us to identify the implications of differences in monitoring for wages and other outcomes, and at the same time allow us to control for unobserved time invariant hotel characteristics that might affect compensation strategies and be correlated with organizational form.

One concern is that those hotels that experience changes in management could be prompted by particularly weak or strong performance, which in either case might be expected to affect compensation levels within an establishment. ${ }^{34}$ Therefore, in one robustness check, we include hotel RevPAR (lagged one year) in $\mathbf{Z}$, which helps to address endogeneity to the extent that changes in performance may affect both wages and the likelihood of changing organizational form. Another concern is that parent companies may have a greater propensity to take over management at franchises with pay policies more similar to those of company managed

\footnotetext{
${ }^{33}$ Note that the establishment effect subsumes any location effect. However, the brand effect can still be identified in regressions with establishment effects because some hotels switch brands during the sample period.

${ }^{34}$ Hotels that are performing poorly or that are failing to meet brand standards are often sold off as independent hotels, in which case they drop out of our sample.
} 
properties, and similarly, may be more likely to relinquish a company managed property to a franchisee if its compensation policies are inconsistent with those of its other properties. However, as we discuss in the results, the bias arising in this case will be toward finding no differences between company managed vs. franchised hotels in their compensation and human resource practices.

In our analysis, we first examine differences between company managed and franchised hotels in log advertised starting wages, which speaks directly to whether company managed hotels might offer lower initial wages (indicative of a tilted wage-tenure profile) or higher initial wages (indicative of efficiency wages) relative to franchised hotels. We also evaluate differences in log highest incumbent wages by occupation across franchised and non-franchised hotels (both deferred-compensation and efficiency wage theories would argue that they should be higher in company managed hotels). Since we do not have information on the tenure of individual workers, we cannot examine differences in the slope of earnings-tenure profiles directly. Instead, we take the log ratio of the highest incumbent wage and the starting wage in an occupation as a proxy for the slope of the wage-tenure profile. While imperfect, given our expansive set of controls (and in particular, our 30 detailed occupation dummies), we believe this difference largely captures variation in wages within occupations in each hotel attributable to pay raises. ${ }^{35}$

In addition to wage levels and dispersion, we also consider differences across franchised and company managed hotels in their propensity to set starting wages equal to the legislated

\footnotetext{
${ }^{35}$ If incumbent wages are, on average, higher in company managed properties, it could reflect the fact that workers at company managed hotels generally have higher tenure, are of higher quality, or are better matched with their respective employers. More dispersion in wages in company managed properties could also simply arise from greater variance in tenure levels among employees. While this is a somewhat different interpretation of the results, such variation in worker characteristics across hotels with different organizational forms could reflect different levels of screening and monitoring that are also consistent with more pronounced agency problems at company managed hotels. In particular, if franchised establishments hire lower quality employees and/or are more likely to catch and dismiss shirking workers than company managed establishments, it could show up as lower average incumbent wage rates and less wage dispersion within occupations.
} 
minimum wage, use probationary wages, offer bonuses, and award raises on the basis of merit rather than on the basis of purely tenure or in step with all other employees at the same establishment. ${ }^{36}$ For each of these four binary outcomes, we use a linear probability model to estimate the effects of different organizational forms. ${ }^{37}$ Examining differences between company managed and franchised hotels in the likelihood of paying the minimum wage to new employees provides another perspective on how agency problems might affect levels of compensation, and as with advertised starting wages, one that circumvents the problem arising from unobserved tenure. Meanwhile, the use of probationary wages is one means by which establishments can tilt the wage-tenure profile. Hence, to the extent that company managed hotels utilize deferred compensation schemes to address their more pronounced monitoring problems, we would expect them to make greater use of probationary wages.

The theory also provides some guidance with respect to which types of establishments would be more likely to use bonuses and merit-based raises. If worker supervision is low, giving bonuses to individual employees or awarding raises on the basis of merit alone could be difficult. Indeed, we might expect franchisees to pay lower salaries but award more bonuses or meritbased raises given their greater propensity to monitor individual workers closely and thereby ascertain which employees are most deserving. As we only observe whether or not bonuses are used and not the precise amounts, we cannot test the proposition that franchised employers offer bonuses sufficiently large that they completely compensate for a lower level of base pay. However, we can determine whether or not there are significant differences across franchised

\footnotetext{
${ }^{36}$ We are missing data for 8,118 observations on methods of awarding raises, so there are fewer observations in samples focusing on this outcome.

${ }^{37}$ Results from fixed effect logit models were qualitatively similar.
} 
and company managed hotels in their use of bonuses and merit-based raises as part of their broader compensation policies. ${ }^{38}$

\section{B. Results}

\section{Baseline Regressions}

We first present results from regressions in which we control for occupation, hotel, and county characteristics and include brand, occupation, county, and year fixed effects. These baseline results appear in Tables 2 and 3. With respect to pay, the results in Table 2 show that on average, advertised starting wages are higher at company managed establishments relative to franchised properties. As column (1) shows, starting wages are a statistically significant $3.4 \%$ higher for employees at company managed hotels relative to employees at comparable franchised hotels on average. Consistent with steeper wage-tenure profiles at company managed properties, the highest wages paid to incumbent employees within occupations are substantially greater in company managed hotels than in franchises; the results indicate that the highest paid incumbents in company managed hotels receive wages that are on average $5.9 \%$ higher than the wages they would receive in franchises. At the mean values in our sample, this implies that the highest paid incumbents at company managed hotels earn on average about 60 cents more per hour than at observationally equivalent franchised hotels.

Also consistent with steeper wage-tenure profiles in company managed hotels, the gap between the highest wage paid and the starting wage in an occupation within a particular hotel chain is $2.5 \%$ greater on average at company managed properties. As previously mentioned, differences in the highest incumbent wage and in the gap between the highest incumbent wage and the starting wage within an occupation could in part reflect differences in average tenure

\footnotetext{
${ }^{38}$ Descriptive statistics for the variables used in the regressions appear in Appendix Table 1.
} 
among workers in different types of hotels. Though we cannot directly address this issue, given the nature of hotel industry and the fact that many jobs are seasonal, tenure is largely a function of occupation. As such, our detailed occupational controls help us to address this concern.

In Table 3, we report the results from linear probability models for other establishment human resource practices, including whether starting wages are equal to the legislated minimum wage, whether the hotel uses probationary wages, whether the hotel offers bonuses to employees, and whether raises in the hotel are awarded on the basis of merit. Consistent with the previous results showing higher average starting wages among company managed hotels, the results in column (1) of Table 3 point to a statistically significant 3\% higher likelihood among franchises to pay new employees the minimum wage. However, relative to franchises, company managed hotels are $9.7 \%$ more likely to use probationary wages, which temporarily reduce pay below the starting wage and effectively increase the slope the wage-tenure profile. Meanwhile, franchises are $9.7 \%$ more likely to offer bonuses, a result consistent with the idea that franchisees, who are likely in a better position to evaluate individual effort, may compensate workers for the lower average wages they offer by providing more performance-based pay. Similarly, the estimates in the final column of Table 3 suggest that merit-based raises are slightly more common in franchises than in company managed properties; we might expect this result if worker effort levels are more easily assessed in franchises relative to company managed properties.

\section{Occupation-Specific Regressions}

Employees in some occupations may be more difficult to monitor than employees in other occupations, in which case we might expect differences across occupations in the extent to which company managed hotels would need to adjust their compensation structures to address agency 
problems. As previously discussed, housekeepers have ample opportunity to shirk. On the other hand, front desk clerks are typically easier to monitor. Not only are the tasks of front desk agents (which largely consist of checking guests in and out) more readily documented and standardized (Talwar 2009), but video and other surveillance technology is more common in hotel lobbies than in guest rooms. Further, unlike housekeepers, front desk agents are not physically dispersed and constantly moving throughout the hotel.

When we consider these two subsets of occupations, we find evidence that the previous results are more likely to be driven by differences in supervision levels than other factors that may differ systematically across company managed and franchised hotels. As the regression results in Table 4 show, for housekeepers, for whom supervision is particularly difficult, the magnitude of the estimates tends to be much larger than for front desk agents, for whom supervision tends to be easier. Indeed, the first two columns of Panel A in Table 4 show that relative to franchises, starting wages and highest incumbent wages for housekeepers in company managed hotels are $3.4 \%$ and $8.2 \%$ higher, respectively. For front desk agents (in Panel B), the results suggest differences across company managed and franchised hotels of $2 \%$ for starting wages and $3.4 \%$ for highest incumbent wages. Similarly, as can be seen in the rightmost columns

of Table 4, differences between company managed hotels and franchised hotels in the likelihood of paying new employees the minimum wage, offering bonuses, and awarding raises based on merit are more pronounced for housekeepers than for front desk agents.

\section{Hotel Fixed Effect Regressions}

The previous results could be biased if there are unobserved hotel characteristics that affect the level and structure of pay within occupations and, at the same time, are correlated with 
organizational form. Hence, exploiting our panel data, we replicate our previous regressions with hotel instead of county fixed effects. We continue to weight the regressions by the number of employees in each occupation and adjust standard errors for heteroscedasticity and hotel-level clusters.

The results, which appear in Table 5, are not appreciably different than those of the baseline regressions in Tables 2 and 3. As column (1) of Table 5 shows, controlling for all observable and unobservable time invariant characteristics of hotels as well as time-varying features of establishments and their local markets, advertised starting wages at company managed hotels are 4.1\% higher than at franchised hotels (a result significant at the $10 \%$ level). The highest incumbent wage at company managed hotels is a statistically significant $7 \%$ higher on average. Though the spread between the highest incumbent wage and the starting wage is not significantly different under different organizational forms, the results are still suggestive of a steeper wagetenure profile at company managed properties. Further evidence of this appears in column (5), which shows that even when controlling for hotel fixed effects, company managed hotels are $15.4 \%$ more likely to use probationary wages. However, differences in the propensity of franchises and company managed properties to offer bonuses or award raises based on merit are not statistically different in these regressions.

Overall, though they are less precise due to the relatively small number of hotels that change organizational form, the estimates from the hotel fixed effect regressions echo those from the baseline regressions. This suggests that the previous results, which indicated that agency problems may induce company managed hotels to adopt compensation policies that tilt the wage- 
tenure profile, were not substantially biased due to the omission of unobserved hotel characteristics. $^{39}$

\section{Compensation and Endogenous Changes in Organizational Form}

As previously discussed, changes in organizational form are not likely to be entirely random. Though changes may be exogenous to compensation and human resource practices in some instances, such as when they take place after a franchise or management contract lapses, we cannot identify the circumstances under which each change in organizational form occurs. It is plausible that particularly strong or weak performance could precipitate changes in organizational form as well as changes in compensation. For example, parent companies may be more likely to take over management of relatively successful franchises, whose wages might be growing more quickly than those of the typical franchise. Similarly, parent companies may be more likely to cede control of a poor performing company managed property to a franchisee, in which case compensation may be growing slower at company managed hotels that switch organizational form relative to those that do not.

To address the possibility that our current set of covariates may not sufficiently capture changes in performance that might trigger changes in organizational form, we include hotel RevPAR as an additional control as a robustness check. We lag RevPAR one year given that it is performance in the recent past rather than contemporaneous performance that will most likely affect compensation for nonsupervisory workers. At the same time, treating RevPAR as a pre-

\footnotetext{
${ }^{39}$ Results from the hotel fixed effects regressions for housekeepers and front desk agents also support our previous conclusion that differences in compensation are likely driven by differences in supervision across hotels with different organizational forms. For housekeepers, the occupation with more pronounced monitoring problems, estimated coefficients on company managed are positive and significant at the $5 \%$ level for highest incumbent wages and the use of probationary wages. However, for the more easily monitored front desk agents, in none of the seven regressions was the estimated coefficient on company managed significant.
} 
determined variable helps to circumvent any reverse causality that might be present between wages and hotel performance. The results appear in Table 6 , where for brevity, we have only included the estimated coefficients on the company managed dummy and on lagged RevPAR. ${ }^{40}$ Due to missing data on revenues, we lose 100 hotels (963 observations) when we control for lagged performance. Thus, for comparison purposes, we include results with and without the RevPAR control. Panel A of Table 6 shows results with county fixed effects, while Panel B shows results with hotel fixed effects. In regressions without hotel fixed effects, wages and the probability of offering bonuses are positively, albeit weakly, related to RevPAR. Interestingly, when we identify the relationships off changes over time within hotels, there is a much stronger positive association between performance and bonuses, but a negative relationship between performance and wages emerges. The latter result may suggest that hotels respond to better performance not by increasing wages for current employees, but rather by hiring new employees who are paid less than average (e.g., part-time workers).

More importantly, however, controlling for hotel performance has very little impact on the magnitudes and significance of the estimated coefficients on the company managed dummy. This is true both in the regressions that exploit inter-hotel variation as well as those that take advantage of intra-hotel changes in organizational form. This suggests that to the extent that there is unobserved variation in performance that might be correlated with both changes in organizational form and with compensation, our existing controls largely capture that variation.

However, changes in organizational form may still be endogenous if, for instance, parent companies are more willing to take over management of franchises whose compensation and

\footnotetext{
${ }^{40}$ The coefficients on the company managed dummy are little changed when we use current as opposed to lagged RevPAR. This is not surprising since, as Stock (2010) notes, even if a control variable (in this case, contemporaneous RevPAR) is correlated with the error term, under the conditional mean independence property, the coefficient on the variable of interest (the company managed dummy) will be unbiased and consistent and can be interpreted as a causal effect.
} 
human resource practices grow more similar to their own over time. Similarly, a company managed property may be more likely to be sold to a franchisee if its personnel policies become inconsistent with those of other company managed properties. In this case, franchises that become company managed are likely to have personnel policies and compensation structures more similar to company managed properties than the typical franchise (and vice versa for company managed properties that become franchises). If this were true, however, it would tend to bias us toward finding no differences in compensation or human resource practices between company managed and franchised hotels. The fact that we continue to find substantive differences across hotels with different organizational forms suggests that variation in monitoring intensity has meaningful implications for wages and personnel policies.

Overall, our results point to the use of deferred compensation as a means to elicit effort from employees and potentially attract more committed applicants. While advertised starting wages are similar at company managed and franchised hotels, the former are much more likely to use probationary wages, which effectively steepen the wage-tenure profile. The relatively high incumbent wages and the larger gap between the highest paid incumbent's wage and the starting wage within detailed occupations at company managed hotels further suggests that workers at franchises experience less wage growth over time. However, franchise workers may be compensated for their lower base pay and weaker wage growth with more performance-based pay, including bonuses. As a result, we cannot conclusively determine whether company managed hotels pay workers more in present value than they would in the full-information case. However, the timing of pay and the extent to which it is tied to individual performance is clearly linked to organizational form, which captures differences in levels of supervision. 


\section{Conclusion}

In this paper, we investigate the relationship between employee supervision and compensation in the hotel industry, in which many chains have both company managed and franchised properties. Our analysis builds upon past research that exploits the particular structure of specific industries to draw inferences about how variation in supervision may affect pay and personnel practices (Krueger 1991, Rebitzer and Taylor 1995). However, relative to the industries considered in previous studies, the hotel industry arguably provides a stronger test of different theories of compensation in the context of imperfect monitoring. Hotels are not only labor-intensive, but they are often expansive, and technology is generally a poor substitute for close human supervision. Meanwhile, differences in incentive structures for salaried managers at company managed properties relative to franchisees naturally give rise to variation in monitoring intensity. These features of the lodging industry, coupled with our rich panel data on hotels, offer a unique opportunity to explore if and how information asymmetries in the workplace affect the structure of compensation and other human resource practices.

Exploiting variation in organizational form both across and within hotels over time, we find evidence that differences in supervision levels affect the timing of pay. In particular, among company managed properties, where employee supervision is likely to be less rigorous compared to franchised properties, the structure of wages suggests the greater use of deferred compensation to induce effort and discourage shirking. While our results are not inconsistent with the use of efficiency wages in hotels with less employee supervision, we cannot rule out the possibility that the present value of career-long wages are equalized across franchised and company managed establishments. Nonetheless, our paper provides compelling evidence that variation in 
monitoring intensity influences the timing of pay and employers' propensity to use certain performance-based incentives, such as bonuses and merit-based raises. 


\section{References}

Akerlof, George and Janet Yellen. 1986. Efficiency Wage Models of the Labor Market.

Cambridge: Cambridge University Press.

Allgulin, Magnus and Tore Ellingsen. 2002. "Monitoring and Pay." Journal of Labor Economics 20(2): 201-216.

Beauchamp, Taylor and Robert Mandelbaum. 2009. "Health Care Legislation - Which Hotels Might Get Sick?” Hotel News Now. November 19.

Blair, Roger and Francine Lafontaine. 2005. The Economics of Franchising. New York: Cambridge University Press.

Bradach, Jeffrey. 1998. Franchise Organizations. Boston: Harvard Business School Press. Brickley, James and Frederick Dark. 1987. "The Choice of Organizational Form: The Case of Franchising." Journal of Financial Economics 18(2): 401-420.

Brickley, James, Frederick Dark, and Michael Weisbach. 1991. “An Agency Perspective on Franchising." Financial Management 20(1): 27-35.

Brown, Michael, Taiping Ho, and Jinlin Zhao. 2009. "Examining Hotel Crimes from Police Crime Reports." Crime Prevention and Community Safety 11(1): 21-33.

Bulow, Jeremy, and Lawrence Summers. 1986. “A Theory of Dual Labor Markets with Application to Industrial Policy, Discrimination, and Keynesian Unemployment." Journal of Labor Economics 4(3): 376-414.

Caves, Richard and William Murphy. 1976. "Franchising: Firms, Markets, and Intangible Assets.” Southern Economic Journal 42(4): 572-586.

Dickens, William, Lawrence Katz, Kevin Lang, and Lawrence Summers. 1989. “Employee Crime and the Monitoring Puzzle.” Journal of Labor Economics 7(3): 331-347. 
Enz, Cathy and Judy Siguaw. 2000. "Best Practices in Human Resources.” Cornell Hospitality Quarterly 41(1): 48-61.

Eyster, James and Jan deRoos. 2009. The Negotiation and Administration of Hotel Management Contracts. $4^{\text {th }}$ Edition. New York: Pearson.

Holmstrom, Bengt and Paul Milgrom. 1991. "Multitask Principal-Agent Analyses: Incentive Contracts, Asset Ownership, and Job Design.” Journal of Law, Economics, and Organization 7(0): 24-52.

Hutchens, Robert. 1987. “A Test of Lazear's Theory of Delayed Payment Contracts.” Journal of Labor Economics 5(4): S153-S170.

Imbens, Guido. 2009. "Better LATE than Nothing: Some Comments on Deaton (2009) and Heckman and Urzua (2009).” NBER Working Paper No. 14896.

International Labour Organization. 2001. "Human Resources Development, Employment and Globalization in the Hotel, Catering and Tourism Sector.” ILO Report TMHCT. http://www.ilo.org/public/english/dialogue/sector/techmeet/tmhct01/tmhct-r.pdf

Kehoe, Michael. 1996. "Franchising, Agency Problems, and the Cost of Capital." Applied Economics 28(11): 1485-1493.

Kennedy, David and Mark. Fulford. 1999. “On the Move: Management Relocation in the Hospitality Industry." Cornell Hotel and Restaurant Administration Quarterly 40(2): 60-68. Krippel, Gregory, Linda Henderson, Marvin Keene, Mariana Levi, and Kelly Converse. 2008. "Employee Theft and the Coastal South Carolina Hospitality Industry: Incidence, Detection, and Response." Tourism and Hospitality Research 8(3): 226-238.

Krueger, Alan. 1991. "Ownership, Agency, and Wages: An Examination of Franchising in the Fast Food Industry." Quarterly Journal of Economics 106(1): 75-101. 
Krueger, Alan and Lawrence Summers. 1988. "Efficiency Wages and the Inter-Industry Wage Structure.” Econometrica 56(2): 259-293.

Kosová, Renáta, Francine Lafontaine, and Rozenn Perrigot. 2010. “Organizational Form and Performance: Evidence from the Hotel Industry." SSRN Working Paper.

Lafontaine, Francine. 1992. “Agency Theory and Franchising: Some Empirical Results.” RAND Journal of Economics 23(2): 263-283.

Lafontaine, Francine and Kathryn Shaw. 2005. “Targeting Managerial Control: Evidence from Franchising." RAND Journal of Economics 36(1): 131-150.

Lafontaine, Francine and Margaret Slade. 2007. "Vertical Integration and Firm Boundaries: The Evidence." Journal of Economic Literature 45(3): 629-685.

Lazear, Edward. 1979. "Why Is There Mandatory Retirement?” Journal of Political Economy 87(6): 1261-1284. . 1981. "Agency, Earnings Profiles, Productivity and Hours Restrictions.” American Economic Review 71(4): 606-620.

Lazear, Edward and Robert Moore. 1984. "Incentives, Productivity, and Labor Contracts.” Quarterly Journal of Economics 99(2): 275-296.

Leonard, Jonathan. "Carrots and Sticks: Pay, Supervision, and Turnover." Journal of Labor Economics 5(4): S135-S152.

Lodging Hospitality. 2008. "Franchise Fact File.” December 1. http://lhonline.com/mag/franchise fact file 1208/index.html. . 2009. "Top Brands.” March 1. http://honline.com/development/franchising/top_brands_7/index.html. 
Mathewson, G. Frank and Ralph Winter. 1985. "The Economics of Franchise Contracts." Journal of Law and Economics 28(3): 503-526.

Michael, Steven. 2000. "The Effect of Organizational Form on Quality: The Case of Franchising." Journal of Economic Behavior and Organization 43(3): 295-318.

Moretti, Enrico and Jeffrey Perloff. 2002. "Efficiency Wages, Deferred Compensation, and Direct Incentives in Agriculture.” American Journal of Agricultural Economics 84(4): 11441155.

Prendergast, Canice. 1999. "The Provision of Incentives in Firms.” Journal of Economic Literature 37(1): 7-63.

Raff, Daniel and Lawrence Summers. 1987. “Did Henry Ford Pay Efficiency Wages?” Journal of Labor Economics 5(4): S57-S86.

Rebitzer, James and Lowell Taylor. 1995. "Efficiency Wages and Employment Rents: The Employer-Size Wage Effect in the Job Market for Lawyers." Journal of Labor Economics 13(4): 678-708.

Ritter, Joseph and Lowell Taylor. 1997. "Economic Models of Employee Motivation." Federal Reserve Bank of St. Louis Review 79(5): 3-21.

Rubin, Paul. 1978. "The Theory of the Firm and the Structure of the Franchise Contract." Journal of Law and Economics 21(1): 223-233.

Rupp, Allison. 2009. “Confessions of... A Hotel Housekeeper: 'Instead of Vacuuming, I Picked Up Some Crumbs."” Arthur Frommer's Budget Travel 12(1): 31.

Rushmore, Stephen, and Erich Baum. 2001. Hotels and Motels: Valuation and Market Studies. Chicago: Appraisal Institute. 
Sappington, David. 1991. "Incentives in Principal-Agent Relationships.” Journal of Economic Perspectives 5(2): 45-66.

Shapiro, Carl, and Joseph Stiglitz. 1984 “Involuntary Unemployment as a Worker Discipline Device." American Economic Review 74(3): 433-444.

Shelton, John. 1967. “Allocative Efficiency vs. 'X-Efficiency: Comment”” American Economic Review 57(5): 1252-1258.

Smith, Devlin. 2001. "Roll Out the Red Carpet: Owning a Hotel Might not be Impossible, But It's Not for Everyone.” Entrepreneur, September 17. http://www.entrepreneur.com/franchises/franchisezone/qanda/article44436.html

Stock, James. 2010. “The Other Transformation in Econometric Practice: Robust Tools for Inference." Journal of Economics Perspectives 24(2): 83-94.

Stutts, Alan and James Wortman. 2006. Hotel and Lodging Management: An Introduction. New York: Wiley.

Talwar, Prakash. 2006. Hotel and Hospitality Management: Housekeeping. Delhi: Isha Books.

Umbreit, W. Terry. 2003. "Effective Performance Appraisal Practices to Enhance Organizational Effectiveness in Hospitality and Tourism.” In Managing Employee Attitudes and Behavior in the Tourism and Hospitality Industry, ed. Salih Kusluvan. New York: Nova Science.

Walker, John and Jack Miller. 2010. Supervision in the Hospitality Industry: Leading Human Resources. $6^{\text {th }}$ Edition. Hoboken, NJ : John Wiley \& Sons.

Warren, Christopher. 2006. “The Franchise Model.” NYSE Magazine 6(6): 18-23.

Woods, Robert, William Heck, and Michael Sciarini. 1998. Turnover and Diversity in the Lodging Industry. Washington DC: American Hotel Foundation.

Wood, Roy. 1992. Working in Hotels and Catering. New York: Routledge. 
Yang, Jen-te. 2004. “Qualitative Knowledge Capturing and Organizational Learning: Two Case Studies in Taiwan Hotels.” Tourism Management 25(4): 421-428.

Yellen, Janet. 1984. "Efficiency Wage Models of Unemployment.” American Economic Review $70(2): 15-25$. 
TABLE 1

SAMPLE DESCRIPTIVE STATISTICS

\begin{tabular}{|c|c|c|c|}
\hline & Company Managed & Franchised & Difference \\
\hline \multicolumn{4}{|c|}{ Panel A: Hotel Characteristics } \\
\hline \multirow[t]{2}{*}{ Number of Rooms } & 127.824 & 127.024 & 0.800 \\
\hline & $(0.900)$ & $(1.753)$ & $(1.797)$ \\
\hline Opening Year & $\begin{array}{c}1993.837 \\
(0.216)\end{array}$ & $\begin{array}{c}1994.981 \\
(0.335)\end{array}$ & $\begin{array}{c}-1.144 * * * \\
(0.399)\end{array}$ \\
\hline \multicolumn{4}{|l|}{ Share of Hotels } \\
\hline \multirow{2}{*}{$\begin{array}{l}\text { With Any Unionized } \\
\text { Emplovees }\end{array}$} & 0.008 & 0.029 & $-0.021 * * *$ \\
\hline & $(0.002)$ & $(0.006)$ & $(0.005)$ \\
\hline \multirow[t]{2}{*}{ With Restaurant } & 0.054 & 0.169 & $-0.116^{* * *}$ \\
\hline & $(0.005)$ & $(0.013)$ & $(0.012)$ \\
\hline \multirow[t]{2}{*}{ In Urban Area } & 0.096 & 0.162 & $-0.066 * * *$ \\
\hline & $(0.007)$ & $(0.013)$ & $(0.013)$ \\
\hline \multirow[t]{2}{*}{ Near Airport } & 0.124 & 0.101 & $0.023^{*}$ \\
\hline & $(0.008)$ & $(0.011)$ & $(0.014)$ \\
\hline \multirow[t]{2}{*}{ On Interstate } & 0.032 & 0.047 & $-0.015^{*}$ \\
\hline & $(0.004)$ & $(0.008)$ & $(0.008)$ \\
\hline \multirow[t]{2}{*}{ In Resort Area } & 0.027 & 0.036 & -0.008 \\
\hline & $(0.004)$ & $(0.007)$ & $(0.007)$ \\
\hline \multirow[t]{2}{*}{ In Suburban Area } & 0.686 & 0.560 & $0.126 * * *$ \\
\hline & $(0.011)$ & $(0.018)$ & $(0.020)$ \\
\hline \multirow[t]{2}{*}{ In Rural Area } & 0.036 & 0.095 & $-0.059 * * *$ \\
\hline & $(0.004)$ & $(0.010)$ & $(0.009)$ \\
\hline \multirow[t]{2}{*}{ In Northeast } & 0.106 & 0.144 & $-0.037 * * *$ \\
\hline & $(0.007)$ & $(0.013)$ & $(0.014)$ \\
\hline \multirow[t]{2}{*}{ In Midwest } & 0.184 & 0.214 & $-0.030^{*}$ \\
\hline & $(0.009)$ & $(0.015)$ & $(0.017)$ \\
\hline \multirow[t]{2}{*}{ In West } & 0.219 & 0.232 & -0.013 \\
\hline & $(0.009)$ & $(0.015)$ & $(0.018)$ \\
\hline \multirow[t]{2}{*}{ In South } & 0.491 & 0.411 & $0.080 * * *$ \\
\hline & $(0.011)$ & $(0.017)$ & $(0.021)$ \\
\hline \multirow{2}{*}{ RevPAR $(\$ 2009)^{+}$} & 49.566 & 73.102 & $-23.536 * * *$ \\
\hline & $(0.568)$ & $(0.887)$ & $(1.050)$ \\
\hline Number of Hotels & 1,900 & 786 & \\
\hline \multicolumn{4}{|c|}{ Panel B: Occupation Characteristics (Weighted by Number of Employees) } \\
\hline \multirow[t]{2}{*}{ Starting Wage (\$2009) } & 9.153 & 8.707 & $0.446 * * *$ \\
\hline & $(0.025)$ & $(0.037)$ & $(0.045)$ \\
\hline \multirow{2}{*}{$\begin{array}{l}\text { Highest Incumbent Wage } \\
\quad \text { (\$2009) }\end{array}$} & 11.021 & 10.382 & $0.639 * * *$ \\
\hline & $(0.031)$ & $(0.050)$ & $(0.059)$ \\
\hline \multirow{2}{*}{$\begin{array}{l}\text { Highest Incumbent Wage/ } \\
\text { Starting Wage }\end{array}$} & 1.218 & 1.209 & 0.009 \\
\hline & $(0.003)$ & $(0.007)$ & $(0.008)$ \\
\hline \multicolumn{4}{|l|}{ Share of Hotels That } \\
\hline Pay Starting Wage Equal & 0.097 & 0.114 & $-0.017 * * *$ \\
\hline to Minimum Wage & $(0.003)$ & $(0.005)$ & $(0.006)$ \\
\hline Use Probationary Wages & 0.183 & 0.157 & $0.025 * * *$ \\
\hline & $(0.004)$ & $(0.006)$ & $(0.007)$ \\
\hline Offer Bonuses & 0.012 & 0.155 & $-0.144 * * *$ \\
\hline & $(0.005)$ & $(0.009)$ & $(0.005)$ \\
\hline Give Merit-Based & 0.821 & 0.687 & $0.133 * * *$ \\
\hline Raises $^{++}$ & $(0.005)$ & $(0.009)$ & $(0.010)$ \\
\hline Observations & 19,020 & 10,559 & \\
\hline
\end{tabular}

Note: Columns (1) and (2) show means for each characteristic with standard errors in parentheses. Differences in means with standard errors in parenthesis appear in column (3). Significant at *10\%; **5\%; ***1\%. ${ }^{+}$Due to missing data, there are 1,849 company managed and 771 franchised hotels with information on revenues per available room (RevPAR). ${ }^{++}$Due to missing data, there are 14,500 observations for company managed and 6,959 observations for franchised hotels with information on methods of awarding raises. 
TABLE 2

BASELINE REGRESSIONS - WAGES

\begin{tabular}{|c|c|c|c|}
\hline & $\begin{array}{l}\text { Log Starting } \\
\text { Wage }\end{array}$ & $\begin{array}{l}\text { Log Highest } \\
\text { Inc. Wage }\end{array}$ & $\begin{array}{l}\text { Log Highest- } \\
\text { Starting Diff. }\end{array}$ \\
\hline Company Managed & $\begin{array}{c}0.033 * * * \\
(0.006)\end{array}$ & $\begin{array}{c}0.057 * * * \\
(0.007)\end{array}$ & $\begin{array}{c}0.025 * * * \\
(0.005)\end{array}$ \\
\hline Unionized & $\begin{array}{l}0.048^{*} \\
(0.029)\end{array}$ & $\begin{array}{c}0.110 * * * \\
(0.034)\end{array}$ & $\begin{array}{c}0.062 * * * \\
(0.020)\end{array}$ \\
\hline Log Number of Rooms & $\begin{array}{c}0.030 * * * \\
(0.008)\end{array}$ & $\begin{array}{c}0.033 * * * \\
(0.011)\end{array}$ & $\begin{array}{c}0.003 \\
(0.008)\end{array}$ \\
\hline Age (Years) & $\begin{array}{c}-0.001 * * * \\
(0.0004)\end{array}$ & $\begin{array}{c}0.001 * * * \\
(0.0003)\end{array}$ & $\begin{array}{c}0.002 * * * \\
(0.0003)\end{array}$ \\
\hline Urban & $\begin{array}{c}0.024 \\
(0.021)\end{array}$ & $\begin{array}{l}0.051 * \\
(0.027)\end{array}$ & $\begin{array}{c}0.027 \\
(0.024)\end{array}$ \\
\hline Airport & $\begin{array}{c}-0.002 \\
(0.020)\end{array}$ & $\begin{array}{c}0.034 \\
(0.026)\end{array}$ & $\begin{array}{c}0.036 \\
(0.024)\end{array}$ \\
\hline Interstate & $\begin{array}{l}-0.011 \\
(0.017)\end{array}$ & $\begin{array}{l}-0.014 \\
(0.022)\end{array}$ & $\begin{array}{l}-0.004 \\
(0.018)\end{array}$ \\
\hline Resort Area & $\begin{array}{l}-0.002 \\
(0.022)\end{array}$ & $\begin{array}{c}0.022 \\
(0.031)\end{array}$ & $\begin{array}{c}0.024 \\
(0.026)\end{array}$ \\
\hline Suburban & $\begin{array}{c}0.003 \\
(0.020)\end{array}$ & $\begin{array}{c}0.024 \\
(0.026)\end{array}$ & $\begin{array}{c}0.021 \\
(0.023)\end{array}$ \\
\hline Extended Stay & $\begin{array}{c}-0.091 * * \\
(0.044)\end{array}$ & $\begin{array}{c}0.045 \\
(0.060)\end{array}$ & $\begin{array}{l}0.136^{*} \\
(0.070)\end{array}$ \\
\hline Restaurant & $\begin{array}{c}0.005 \\
(0.008)\end{array}$ & $\begin{array}{l}-0.006 \\
(0.010)\end{array}$ & $\begin{array}{l}-0.010 \\
(0.008)\end{array}$ \\
\hline Convention Facilities & $\begin{array}{c}-0.092 * * * \\
(0.034)\end{array}$ & $\begin{array}{l}-0.040 \\
(0.038)\end{array}$ & $\begin{array}{c}0.052 \\
(0.045)\end{array}$ \\
\hline Boutique & $\begin{array}{c}0.169 * * * \\
(0.036)\end{array}$ & $\begin{array}{c}0.189 * * * \\
(0.036)\end{array}$ & $\begin{array}{c}0.020 \\
(0.034)\end{array}$ \\
\hline All Suites & $\begin{array}{l}-0.012 \\
(0.023)\end{array}$ & $\begin{array}{l}-0.053^{*} \\
(0.029)\end{array}$ & $\begin{array}{l}-0.040 \\
(0.025)\end{array}$ \\
\hline Log County Employment & $\begin{array}{l}-0.176 \\
(0.111)\end{array}$ & $\begin{array}{l}-0.081 \\
(0.099)\end{array}$ & $\begin{array}{c}0.095 \\
(0.095)\end{array}$ \\
\hline County Unemployment Rate & $\begin{array}{c}-0.011 * * * \\
(0.003)\end{array}$ & $\begin{array}{l}-0.003 \\
(0.003)\end{array}$ & $\begin{array}{c}0.008 * * * \\
(0.003)\end{array}$ \\
\hline County Share Black & $\begin{array}{l}-0.412 \\
(0.717)\end{array}$ & $\begin{array}{l}-0.401 \\
(0.711)\end{array}$ & $\begin{array}{c}0.011 \\
(0.632)\end{array}$ \\
\hline Log County Average Weekly Wage & $\begin{array}{c}0.264^{* *} \\
(0.117)\end{array}$ & $\begin{array}{c}0.429 * * * \\
(0.122)\end{array}$ & $\begin{array}{c}0.165^{* *} \\
(0.082)\end{array}$ \\
\hline No. of Other Hotels in County & $\begin{array}{c}0.001 * * * \\
(0.0004)\end{array}$ & $\begin{array}{c}0.002 * * * \\
(0.0004)\end{array}$ & $\begin{array}{c}0.001^{*} \\
(0.0003)\end{array}$ \\
\hline Constant & $\begin{array}{c}1.980 \\
(1.576)\end{array}$ & $\begin{array}{c}-0.634 \\
(1.540)\end{array}$ & $\begin{array}{l}-2.613^{*} \\
(1.366)\end{array}$ \\
\hline R-Squared & 0.693 & 0.593 & 0.251 \\
\hline Observations & 29,579 & 29,579 & 29,579 \\
\hline Brand Fixed Effects & 82 & 82 & 82 \\
\hline Occupation Fixed Effects & 30 & 30 & 30 \\
\hline County Fixed Effects & 436 & 436 & 436 \\
\hline
\end{tabular}

Note: In addition to brand, occupation, and county fixed effects, all specifications include 5 price range and 7 year dummies. Robust standard errors adjusted for heteroscedasticity and clusters at the hotel level in parentheses. Significant at $* 10 \% ; * * 5 \% ; * * * 1 \%$. 
TABLE 3

BASELINe Regressions - HuMAN RESOURCE PRACTICES

\begin{tabular}{|c|c|c|c|c|}
\hline & $\begin{array}{c}\text { Start. Wage = } \\
\text { Min. Wage }\end{array}$ & $\begin{array}{c}\text { Probationary } \\
\text { Wages }\end{array}$ & Bonus & $\begin{array}{c}\text { Merit-Based } \\
\text { Raises }\end{array}$ \\
\hline \multirow[t]{2}{*}{ Company Managed } & $-0.030 * * *$ & $0.097 * * *$ & $-0.097 * * *$ & $-0.062 *$ \\
\hline & $(0.008)$ & $(0.020)$ & $(0.012)$ & $(0.034)$ \\
\hline \multirow[t]{2}{*}{ Unionized } & $-0.098 * * *$ & 0.007 & -0.006 & 0.033 \\
\hline & $(0.032)$ & $(0.035)$ & $(0.037)$ & $(0.071)$ \\
\hline \multirow[t]{2}{*}{ Log Number of Rooms } & -0.008 & -0.036 & -0.014 & $-0.077 * *$ \\
\hline & $(0.011)$ & $(0.025)$ & $(0.015)$ & $(0.037)$ \\
\hline \multirow[t]{2}{*}{ Age (Years) } & -0.0002 & $-0.002 * *$ & -0.0005 & -0.001 \\
\hline & $(0.0003)$ & $(0.001)$ & $(0.001)$ & $(0.001)$ \\
\hline \multirow{2}{*}{ Urban } & 0.022 & 0.039 & -0.013 & -0.013 \\
\hline & $(0.042)$ & $(0.058)$ & $(0.045)$ & $(0.076)$ \\
\hline \multirow[t]{2}{*}{ Airport } & 0.017 & 0.010 & -0.032 & 0.006 \\
\hline & $(0.042)$ & $(0.056)$ & $(0.043)$ & $(0.071)$ \\
\hline \multirow[t]{2}{*}{ Interstate } & $0.109 * *$ & 0.036 & -0.047 & -0.008 \\
\hline & $(0.047)$ & $(0.053)$ & $(0.040)$ & $(0.064)$ \\
\hline \multirow[t]{2}{*}{ Resort Area } & 0.038 & -0.080 & 0.006 & 0.087 \\
\hline & $(0.044)$ & $(0.070)$ & $(0.051)$ & $(0.084)$ \\
\hline \multirow{2}{*}{ Suburban } & 0.016 & -0.012 & -0.027 & 0.019 \\
\hline & $(0.041)$ & $(0.053)$ & $(0.041)$ & $(0.069)$ \\
\hline \multirow[t]{2}{*}{ Extended Stay } & -0.056 & $0.347 * * *$ & 0.059 & -0.050 \\
\hline & $(0.041)$ & $(0.129)$ & $(0.082)$ & $(0.163)$ \\
\hline \multirow{2}{*}{ Restaurant } & 0.003 & -0.017 & 0.018 & 0.034 \\
\hline & $(0.013)$ & $(0.026)$ & $(0.015)$ & $(0.039)$ \\
\hline \multirow[t]{2}{*}{ Convention Facilities } & $0.171 * * *$ & $0.284 *$ & 0.011 & 0.075 \\
\hline & $(0.047)$ & $(0.153)$ & $(0.039)$ & $(0.142)$ \\
\hline \multirow[t]{2}{*}{ Boutique } & $-0.360 * * *$ & 0.019 & 0.012 & -0.509 \\
\hline & $(0.065)$ & $(0.103)$ & $(0.049)$ & $(0.311)$ \\
\hline \multirow[t]{2}{*}{ All Suites } & 0.072 & 0.048 & -0.045 & 0.029 \\
\hline & $(0.046)$ & $(0.065)$ & $(0.037)$ & $(0.082)$ \\
\hline \multirow{2}{*}{ Log County Employment } & 0.163 & 0.053 & -0.002 & -0.300 \\
\hline & (0.109) & $(0.374)$ & $(0.161)$ & $(0.274)$ \\
\hline \multirow[t]{2}{*}{ County Unemployment Rate } & -0.002 & -0.001 & 0.005 & -0.011 \\
\hline & $(0.005)$ & $(0.011)$ & $(0.006)$ & $(0.010)$ \\
\hline \multirow[t]{2}{*}{ County Share Black } & 0.073 & 2.750 & 0.467 & -1.387 \\
\hline & $(0.712)$ & (2.579) & (1.104) & (2.793) \\
\hline \multirow[t]{2}{*}{ Log County Average Weekly Wage } & $0.232 *$ & 0.102 & -0.054 & $0.771^{* *}$ \\
\hline & $(0.140)$ & $(0.336)$ & $(0.199)$ & $(0.342)$ \\
\hline \multirow[t]{2}{*}{ No. of Other Hotels in County } & $0.003 * * *$ & -0.001 & $0.001 * *$ & $0.002 *$ \\
\hline & $(0.001)$ & $(0.001)$ & $(0.0005)$ & $(0.001)$ \\
\hline \multirow[t]{2}{*}{ Constant } & $-3.165^{*}$ & -1.252 & 0.340 & -0.0001 \\
\hline & $(1.851)$ & $(5.299)$ & $(2.558)$ & $(4.159)$ \\
\hline R-Squared & 0.372 & 0.534 & 0.333 & 0.568 \\
\hline Observations & 29,579 & 29,579 & 29,579 & 21,459 \\
\hline Brand Fixed Effects & 82 & 82 & 82 & 78 \\
\hline Occupation Fixed Effects & 30 & 30 & 30 & 30 \\
\hline County Fixed Effects & 436 & 436 & 436 & 406 \\
\hline
\end{tabular}

Note: In addition to brand, occupation, and county fixed effects, all specifications include 5 price range and 7 year dummies. Robust standard errors adjusted for heteroscedasticity and clusters at the hotel level in parentheses. Significant at $* 10 \% ; * * 5 \%$; $* * * 1 \%$. 
TABLE 4

BASELINE REGRESSIONS - SPECIFIC OCCUPATIONS

\begin{tabular}{|c|c|c|c|c|c|c|c|}
\hline & $\begin{array}{c}\text { Log Starting } \\
\text { Wage }\end{array}$ & $\begin{array}{l}\text { Log Highest } \\
\text { Inc. Wage }\end{array}$ & $\begin{array}{l}\text { Log Highest- } \\
\text { Starting Diff. }\end{array}$ & $\begin{array}{c}\text { Start. Wage = } \\
\text { Min. Wage }\end{array}$ & $\begin{array}{c}\text { Probationary } \\
\text { Wages }\end{array}$ & Bonus & $\begin{array}{c}\text { Merit-Based } \\
\text { Raises }\end{array}$ \\
\hline \multicolumn{8}{|c|}{ Panel A: Housekeepers } \\
\hline Company Managed & $\begin{array}{c}0.033 * * * \\
(0.006)\end{array}$ & $\begin{array}{c}0.079 * * * \\
(0.008)\end{array}$ & $\begin{array}{c}0.046^{* * *} \\
(0.007)\end{array}$ & $\begin{array}{c}-0.034 * * \\
(0.015)\end{array}$ & $\begin{array}{c}0.108 * * * \\
(0.021)\end{array}$ & $\begin{array}{c}-0.097 * * * \\
(0.015)\end{array}$ & $\begin{array}{c}-0.074 * \\
(0.038)\end{array}$ \\
\hline Unionized & $\begin{array}{c}0.051 \\
(0.034)\end{array}$ & $\begin{array}{c}0.086^{* * *} * \\
(0.033)\end{array}$ & $\begin{array}{c}0.035 \\
(0.031)\end{array}$ & $\begin{array}{c}-0.095 * * \\
(0.039)\end{array}$ & $\begin{array}{c}0.023 \\
(0.054)\end{array}$ & $\begin{array}{c}0.060 \\
(0.056)\end{array}$ & $\begin{array}{l}-0.049 \\
(0.117)\end{array}$ \\
\hline Log Number of Rooms & $\begin{array}{c}0.032 * * * \\
(0.010)\end{array}$ & $\begin{array}{c}0.033 * * \\
(0.015)\end{array}$ & $\begin{array}{l}0.0003 \\
(0.011)\end{array}$ & $\begin{array}{l}-0.006 \\
(0.020)\end{array}$ & $\begin{array}{c}-0.038 \\
(0.027)\end{array}$ & $\begin{array}{l}-0.008 \\
(0.016)\end{array}$ & $\begin{array}{c}-0.081 * * \\
(0.041)\end{array}$ \\
\hline Age (Years) & $\begin{array}{c}-0.001 * * * \\
(0.0003)\end{array}$ & $\begin{array}{c}0.001 * * * \\
(0.0004)\end{array}$ & $\begin{array}{c}0.002 * * * \\
(0.0004)\end{array}$ & $\begin{array}{c}-0.001 * * \\
(0.001)\end{array}$ & $\begin{array}{c}-0.002 * * \\
(0.001)\end{array}$ & $\begin{array}{l}0.0001 \\
(0.001)\end{array}$ & $\begin{array}{c}-0.0002 \\
(0.001)\end{array}$ \\
\hline Observations & 6,222 & 6,222 & 6,222 & 6,222 & 6,222 & 6,222 & 4,699 \\
\hline \multicolumn{8}{|c|}{ Panel B: Front Desk Agents } \\
\hline Company Managed & $\begin{array}{c}0.020 * * * \\
(0.006)\end{array}$ & $\begin{array}{c}0.033 * * * \\
(0.009)\end{array}$ & $\begin{array}{c}0.013 \\
(0.010)\end{array}$ & $\begin{array}{l}-0.008^{*} \\
(0.004)\end{array}$ & $\begin{array}{c}0.116^{* * *} * \\
(0.020)\end{array}$ & $\begin{array}{c}-0.085^{* * *} \\
(0.013)\end{array}$ & $\begin{array}{c}-0.030 \\
(0.038)\end{array}$ \\
\hline Unionized & $\begin{array}{c}0.028 \\
(0.037)\end{array}$ & $\begin{array}{l}0.080 * \\
(0.044)\end{array}$ & $\begin{array}{c}0.052 \\
(0.041)\end{array}$ & $\begin{array}{l}-0.013 \\
(0.013)\end{array}$ & $\begin{array}{c}0.104 \\
(0.077)\end{array}$ & $\begin{array}{l}-0.049 \\
(0.036)\end{array}$ & $\begin{array}{c}0.165 \\
(0.154)\end{array}$ \\
\hline Log Number of Rooms & $\begin{array}{c}0.044 * * * \\
(0.009)\end{array}$ & $\begin{array}{l}0.022 * \\
(0.012)\end{array}$ & $\begin{array}{c}-0.022^{* *} \\
(0.011)\end{array}$ & $\begin{array}{l}-0.001 \\
(0.006)\end{array}$ & $\begin{array}{l}-0.029 \\
(0.026)\end{array}$ & $\begin{array}{l}-0.005 \\
(0.018)\end{array}$ & $\begin{array}{l}-0.058 \\
(0.038)\end{array}$ \\
\hline Age (Years) & $\begin{array}{c}-0.001 * * * \\
(0.0002)\end{array}$ & $\begin{array}{c}0.001 \\
(0.0004)\end{array}$ & $\begin{array}{c}0.001 * * * \\
(0.0004)\end{array}$ & $\begin{array}{c}-0.0001 \\
(0.0002)\end{array}$ & $\begin{array}{c}-0.003 * * \\
(0.001)\end{array}$ & $\begin{array}{r}-0.0002 \\
(0.001)\end{array}$ & $\begin{array}{l}-0.001 \\
(0.001)\end{array}$ \\
\hline Observations & 4,298 & 4,298 & 4,298 & 4,298 & 4,298 & 4,298 & 3,214 \\
\hline Brand Fixed Effects & 82 & 82 & 82 & 82 & 82 & 82 & 78 \\
\hline County Fixed Effects & 436 & 436 & 436 & 436 & 436 & 436 & 406 \\
\hline
\end{tabular}

Note: All specifications include the same location, amenity, and county characteristics included in the baseline regressions in Tables 2 and 3 along with 5 price range and 7 year dummies. Robust standard errors adjusted for heteroscedasticity and clusters at the hotel level in parentheses. Significant at *10\%; **5\%; ***1\%. 
TABLE 5

HOTEL FIXED EFFECT REGRESSIONS

\begin{tabular}{|c|c|c|c|c|c|c|c|}
\hline & $\begin{array}{c}\text { Log Starting } \\
\text { Wage }\end{array}$ & $\begin{array}{l}\text { Log Highest } \\
\text { Inc. Wage }\end{array}$ & $\begin{array}{l}\text { Log Highest- } \\
\text { Starting Diff. }\end{array}$ & $\begin{array}{l}\text { Start. Wage = } \\
\text { Min. Wage }\end{array}$ & $\begin{array}{c}\text { Probationary } \\
\text { Wages }\end{array}$ & Bonus & $\begin{array}{c}\text { Merit-Based } \\
\text { Raises }\end{array}$ \\
\hline \multirow[t]{2}{*}{ Company Managed } & $0.040 *$ & $0.068 * *$ & 0.028 & -0.030 & $0.154 *$ & 0.017 & -0.028 \\
\hline & $(0.022)$ & $(0.026)$ & $(0.024)$ & $(0.032)$ & $(0.089)$ & $(0.029)$ & $(0.048)$ \\
\hline \multirow[t]{2}{*}{ Unionized } & 0.078 & 0.095 & 0.017 & $-0.181 * * *$ & -0.043 & -0.024 & -0.042 \\
\hline & $(0.049)$ & $(0.066)$ & $(0.027)$ & $(0.041)$ & $(0.053)$ & $(0.034)$ & $(0.055)$ \\
\hline \multirow[t]{2}{*}{ Log Number of Rooms } & 0.007 & -0.002 & $-0.009 *$ & 0.013 & $0.023 * * *$ & $0.010 * * *$ & 0.012 \\
\hline & $(0.006)$ & $(0.011)$ & $(0.005)$ & $(0.039)$ & $(0.007)$ & $(0.003)$ & $(0.010)$ \\
\hline \multirow[t]{2}{*}{ Age (Years) } & 0.009 & 0.003 & -0.006 & 0.004 & $-0.055 * *$ & -0.024 & -0.021 \\
\hline & $(0.006)$ & $(0.004)$ & $(0.004)$ & $(0.006)$ & $(0.022)$ & $(0.017)$ & $(0.017)$ \\
\hline \multirow[t]{2}{*}{ Log County Employment } & $-0.291 * *$ & -0.092 & $0.199 *$ & $0.347 * *$ & 0.036 & -0.136 & -0.664 \\
\hline & $(0.125)$ & $(0.118)$ & $(0.102)$ & $(0.147)$ & $(0.421)$ & $(0.195)$ & $(0.471)$ \\
\hline \multirow{2}{*}{ County Unemployment Rate } & $-0.009 * * *$ & -0.004 & $0.005^{*}$ & -0.006 & -0.006 & 0.012 & 0.002 \\
\hline & $(0.003)$ & $(0.004)$ & $(0.003)$ & $(0.007)$ & $(0.014)$ & $(0.008)$ & $(0.009)$ \\
\hline \multirow[t]{2}{*}{ County Share Black } & $-1.474^{*}$ & -1.121 & 0.353 & 0.153 & 1.375 & 0.886 & 4.623 \\
\hline & $(0.808)$ & $(0.892)$ & $(0.936)$ & $(1.001)$ & $(3.245)$ & (1.132) & $(4.624)$ \\
\hline \multirow{2}{*}{$\begin{array}{l}\text { Log County Average Weekly } \\
\text { Wage }\end{array}$} & 0.070 & $0.239 * *$ & $0.169 * *$ & $0.353 * *$ & 0.254 & -0.212 & $0.670 *$ \\
\hline & $(0.097)$ & $(0.099)$ & $(0.082)$ & $(0.176)$ & $(0.365)$ & $(0.234)$ & $(0.352)$ \\
\hline \multirow{2}{*}{$\begin{array}{l}\text { No. of Other Hotels in } \\
\text { County }\end{array}$} & 0.001 & $0.001 * *$ & 0.0004 & $0.003 * * *$ & -0.0002 & $0.001 * *$ & 0.001 \\
\hline & $(0.001)$ & $(0.0005)$ & $(0.0004)$ & $(0.001)$ & $(0.001)$ & $(0.001)$ & $(0.002)$ \\
\hline \multirow[t]{2}{*}{ Constant } & $4.990 * * *$ & 1.293 & $-3.697 * *$ & $-6.637 * * *$ & -1.469 & 2.880 & 4.067 \\
\hline & $(1.658)$ & $(1.576)$ & $(1.506)$ & $(2.446)$ & $(6.238)$ & $(2.823)$ & $(5.636)$ \\
\hline R-Squared & 0.755 & 0.687 & 0.415 & 0.495 & 0.741 & 0.580 & 0.853 \\
\hline Observations & 29,579 & 29,579 & 29,579 & 29,579 & 29,579 & 29,579 & 21,459 \\
\hline Brand Fixed Effects & 82 & 82 & 82 & 82 & 82 & 82 & 78 \\
\hline Occupation Fixed Effects & 30 & 30 & 30 & 30 & 30 & 30 & 30 \\
\hline Hotel Fixed Effects & 2,686 & 2,686 & 2,686 & 2,686 & 2,686 & 2,686 & 2,243 \\
\hline
\end{tabular}

Note: In addition to brand, occupation, and hotel fixed effects, all specifications include 7 year dummies. Robust standard errors adjusted for heteroscedasticity and clusters at the hotel level in parentheses. Significant at $* 10 \% ; * * 5 \% ; * * * 1 \%$. 
TABLE 6

REGRESSIONS WITH PERFORMANCE CONTROLS

\begin{tabular}{|c|c|c|c|c|c|c|c|}
\hline & $\begin{array}{c}\text { Log Starting } \\
\text { Wage }\end{array}$ & $\begin{array}{c}\text { Log Highest } \\
\text { Inc. Wage }\end{array}$ & $\begin{array}{l}\text { Log Highest- } \\
\text { Starting Diff. }\end{array}$ & $\begin{array}{c}\text { Start. Wage = } \\
\text { Min. Wage }\end{array}$ & $\begin{array}{c}\text { Probationary } \\
\text { Wages }\end{array}$ & Bonus & $\begin{array}{c}\text { Merit-Based } \\
\text { Raises }\end{array}$ \\
\hline \multicolumn{8}{|c|}{ Panel A: Baseline Regressions } \\
\hline \multicolumn{8}{|c|}{ Without Performance Controls } \\
\hline Company Managed & $\begin{array}{c}0.034 * * * \\
(0.006) \\
\end{array}$ & $\begin{array}{c}0.058 * * * \\
(0.007) \\
\end{array}$ & $\begin{array}{c}0.023 * * * \\
(0.005) \\
\end{array}$ & $\begin{array}{c}-0.029 * * * \\
(0.008) \\
\end{array}$ & $\begin{array}{c}0.094 * * * \\
(0.019) \\
\end{array}$ & $\begin{array}{c}-0.101 * * * \\
(0.013) \\
\end{array}$ & $\begin{array}{c}-0.059 * \\
(0.034) \\
\end{array}$ \\
\hline \multicolumn{8}{|c|}{ With Performance Controls } \\
\hline Company Managed & $\begin{array}{c}0.034 * * * \\
(0.006)\end{array}$ & $\begin{array}{c}0.058 * * * \\
(0.007)\end{array}$ & $\begin{array}{c}0.023 * * * \\
(0.005)\end{array}$ & $\begin{array}{c}-0.029 * * * \\
(0.008)\end{array}$ & $\begin{array}{c}0.095 * * * \\
(0.019)\end{array}$ & $\begin{array}{c}-0.101 * * * \\
(0.013)\end{array}$ & $\begin{array}{l}-0.059^{*} \\
(0.034)\end{array}$ \\
\hline Log RevPAR (Lagged) & $\begin{array}{c}0.014 \\
(0.012)\end{array}$ & $\begin{array}{c}0.026^{* *} \\
(0.013)\end{array}$ & $\begin{array}{c}0.012 \\
(0.011)\end{array}$ & $\begin{array}{c}-0.018 \\
(0.016)\end{array}$ & $\begin{array}{c}0.120 * * * \\
(0.029)\end{array}$ & $\begin{array}{c}0.031 \\
(0.023)\end{array}$ & $\begin{array}{c}-0.029 \\
(0.043)\end{array}$ \\
\hline \multicolumn{8}{|c|}{ Panel B: Hotel Fixed Effect Regressions } \\
\hline \multicolumn{8}{|c|}{ Without Performance Controls } \\
\hline Company Managed & $\begin{array}{c}0.030 \\
(0.020)\end{array}$ & $\begin{array}{c}0.065 * * \\
(0.028)\end{array}$ & $\begin{array}{c}0.034 \\
(0.025)\end{array}$ & $\begin{array}{l}-0.025 \\
(0.034)\end{array}$ & $\begin{array}{c}0.123 \\
(0.088)\end{array}$ & $\begin{array}{c}0.026 \\
(0.031)\end{array}$ & $\begin{array}{c}-0.036 \\
(0.051)\end{array}$ \\
\hline \multicolumn{8}{|c|}{ With Performance Controls } \\
\hline Company Managed & $\begin{array}{c}0.030 \\
(0.020)\end{array}$ & $\begin{array}{c}0.064 * * \\
(0.027)\end{array}$ & $\begin{array}{c}0.034 \\
(0.024)\end{array}$ & $\begin{array}{l}-0.026 \\
(0.034)\end{array}$ & $\begin{array}{c}0.127 \\
(0.087)\end{array}$ & $\begin{array}{c}0.028 \\
(0.031)\end{array}$ & $\begin{array}{l}-0.034 \\
(0.051)\end{array}$ \\
\hline Log RevPAR (Lagged) & $\begin{array}{l}-0.005 \\
(0.015)\end{array}$ & $\begin{array}{c}-0.041 * * \\
(0.019)\end{array}$ & $\begin{array}{c}-0.036 * * \\
(0.016)\end{array}$ & $\begin{array}{l}-0.053^{*} \\
(0.032)\end{array}$ & $\begin{array}{c}0.301 * * * \\
(0.066)\end{array}$ & $\begin{array}{c}0.118 * * * \\
(0.039)\end{array}$ & $\begin{array}{c}0.045 \\
(0.063)\end{array}$ \\
\hline Observations & 28,616 & 28,616 & 28,616 & 28,616 & 28,616 & 28,616 & 20,704 \\
\hline Brand Fixed Effects & 78 & 78 & 78 & 78 & 78 & 78 & 75 \\
\hline Occupation Fixed Effects & 30 & 30 & 30 & 30 & 30 & 30 & 30 \\
\hline County Fixed Effects (Panel A) & 427 & 427 & 427 & 427 & 427 & 427 & 401 \\
\hline Hotel Fixed Effects (Panel B) & 2,586 & 2,586 & 2,586 & 2,586 & 2,586 & 2,586 & 2,158 \\
\hline
\end{tabular}

Note: All specifications include the same variables as in Tables 2 and 3 (Panel A) and Table 5 (Panel B). Robust standard errors adjusted for heteroscedasticity and clusters at the hotel level in parentheses. Significant at $* 10 \% ; * * 5 \% ; * * * 1 \%$. 


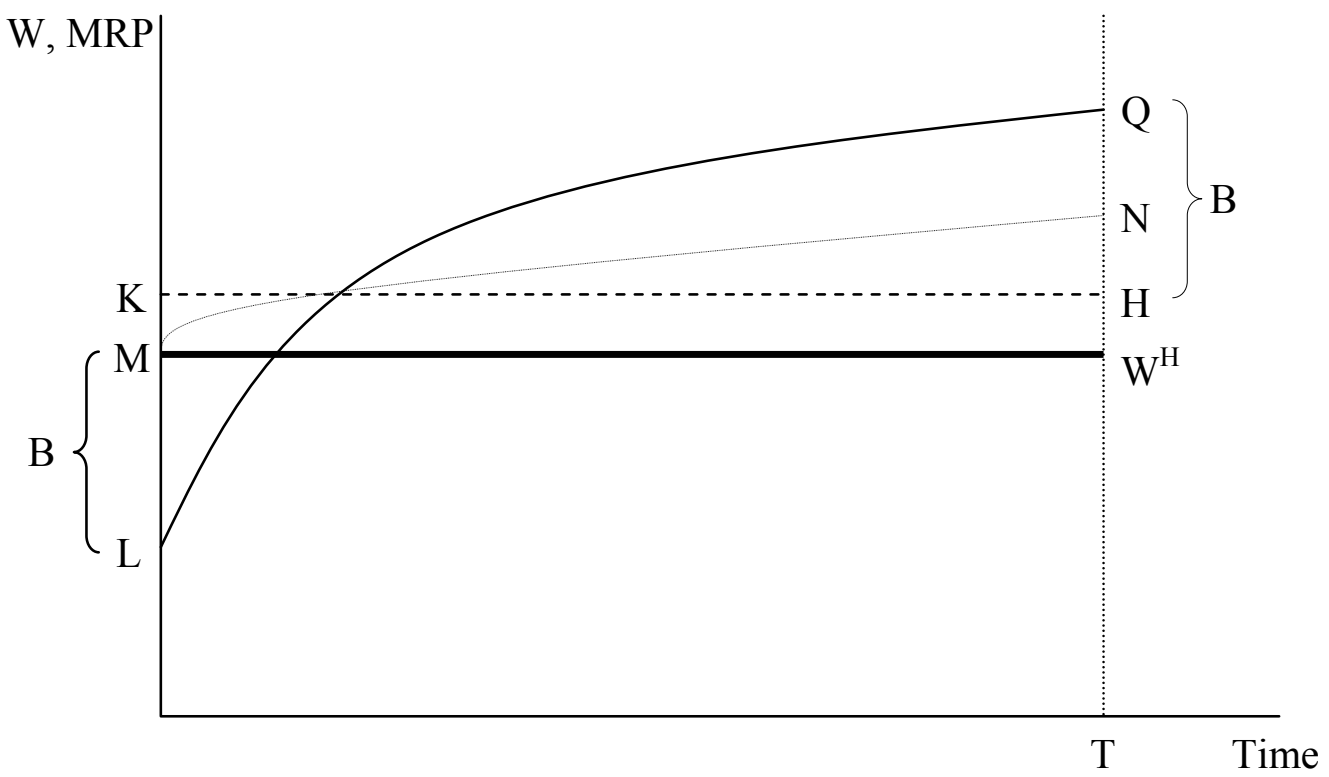

FIG. 1.-Alternative wage-tenure profiles. 


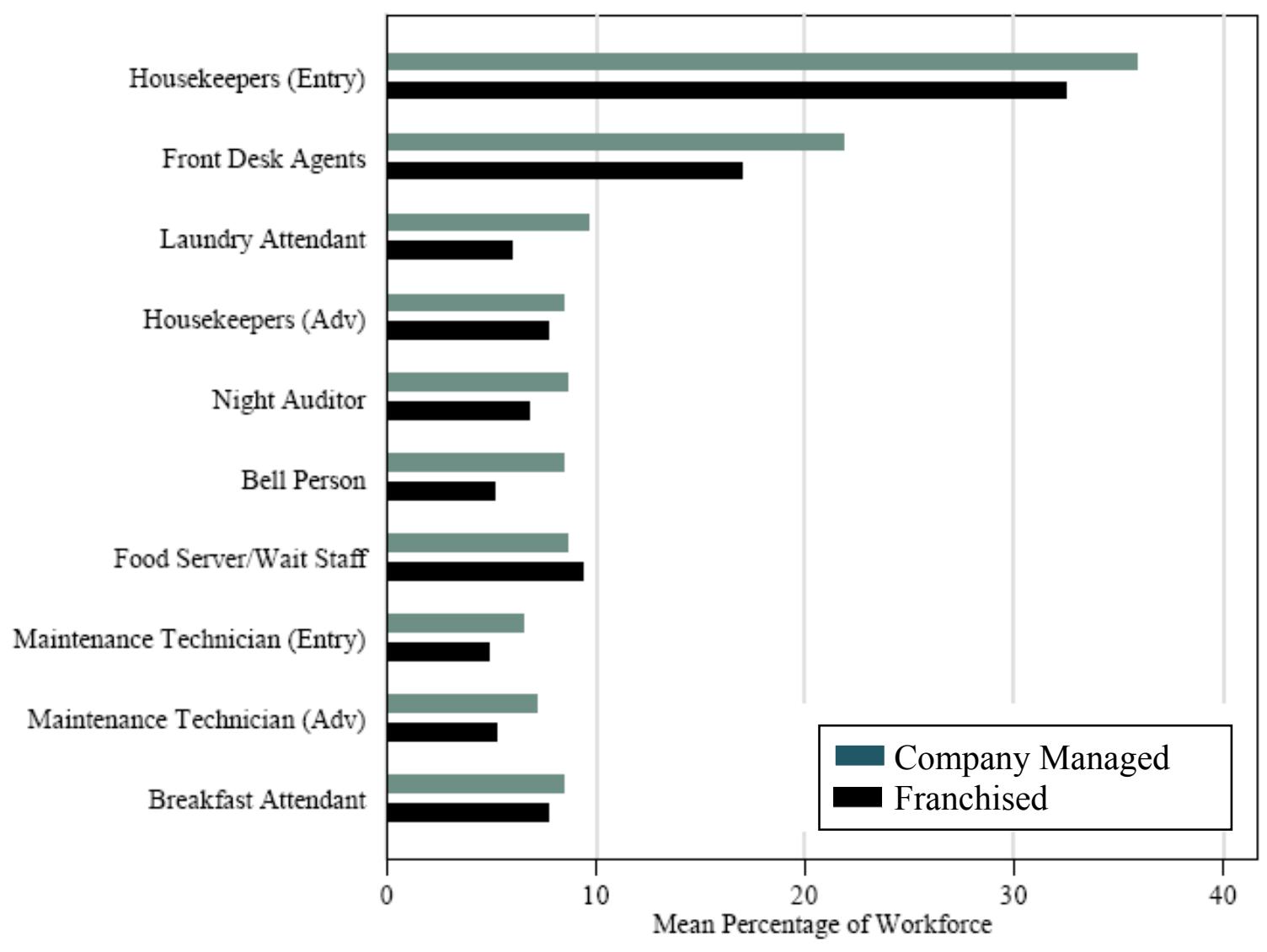

FIG. 2.-Distribution of Employment - Top 10 Occupations in Limited Service Hotels 